\title{
INFLAMMATORY AND CATABOLIC SIGNALLING IN INTERVERTEBRAL DISCS: THE ROLES OF NF-KB AND MAP KINASES
}

\author{
Karin Wuertz ${ }^{1,2,3,4^{*}}$, Nam Vo ${ }^{5}$, Dimitris Kletsas ${ }^{6}$ and Norbert Boos ${ }^{1,3}$ \\ ${ }^{1}$ Spine Research Group, Competence Centre for Applied Biotechnology and Molecular Medicine, \\ University of Zurich, Zurich, Switzerland \\ ${ }^{2}$ Zurich Center for Integrative Human Physiology (ZIHP), University of Zurich, Zurich, Switzerland \\ ${ }^{3}$ AOSpine Research Network, Duebendorf, Switzerland \\ ${ }^{4}$ Institute for Biomechanics, ETH Zurich, Zurich, Switzerland \\ ${ }^{5}$ Ferguson Laboratory for Orthopaedic Research, Department of Orthopaedic Surgery, University of Pittsburgh \\ School of Medicine, Pittsburgh, USA \\ ${ }^{6}$ Laboratory of Cell Proliferation \& Ageing, Institute of Biology, NCSR "Demokritos", Athens, Greece
}

\begin{abstract}
Painful intervertebral disc disease is characterised not only by an imbalance between anabolic (i.e., matrix synthesis) and catabolic (i.e., matrix degradation) processes, but also by inflammatory mechanisms. The increased expression and synthesis of matrix metalloproteinases and inflammatory factors is mediated by specific signal transduction, in particular the nuclear factor-kappaB $(\mathrm{NF}-\kappa \mathrm{B})$ and mitogen-activated protein kinase (MAPK)-mediated pathways. NF- $\mathrm{B}$ and MAPK have been identified as the master regulators of inflammation and catabolism in several musculoskeletal disorders (e.g., osteoarthritis), and recently growing evidence supports the importance of these signalling pathways in painful disc disease. With continuing research exploiting in vitro and in vivo model systems to elucidate the roles of these pathways in disc degeneration, it may be possible in the near future to specifically target these major inflammatory / catabolic signalling pathways to treat painful degenerative disc disease. In this perspective, we aim to summarise the current state of knowledge concerning the inflammatory and catabolic molecular pathways of intervertebral disc disease (IDD), with a detailed description of NF- $\kappa \mathrm{B}$ and MAP kinase-mediated signal transduction in disc cells. Furthermore, we will discuss the emerging novel molecular treatment modalities for IDD using pharmacological inhibitors targeting these pathways.
\end{abstract}

Keywords: nuclear factor kappa B, NF-кB, MAP kinases, MAPK, intervertebral disc, IVD, signalling, target genes, activation, inhibition

*Address for Correspondence:

Dr. Karin Wuertz

Spine Research Group

Competence Center for Applied Biotechnology and Molecular Medicine (CABMM)

University of Zurich

Winterthurerstrasse 190 (17L28)

8057 Zurich, Switzerland

Telephone Number: +4144635 5497

FAX Number: +41446356840

E-Mail: karin.wuertz@cabmm.uzh.ch

\begin{tabular}{|c|c|}
\hline ASIC & Acid-sensing ion channel \\
\hline ASS & Acetylic salicylic acid \\
\hline $\mathrm{AF}$ & Annulus fibrosus \\
\hline $\mathrm{COX}$ & Cyclooxygenase \\
\hline CPB & Creb-binding protein \\
\hline EG-1 & Early growth factor 1 \\
\hline EMSA & Electrophoretic mobility shift analysis \\
\hline EP & Endplate \\
\hline ERK & Extracellular signal-regulated kinase \\
\hline bFGF & Basic fibroblast growth factor \\
\hline Gluc AT-1 & $\beta$-1,3-glucuronyl-transferase 1 \\
\hline IDD & Intervertebral disc disease \\
\hline IGF-I & Insulin-like growth factor-I \\
\hline IL & Interleukin \\
\hline ІкB & Inhibitor of $\kappa \mathrm{B}$ \\
\hline IKK & IкB kinase \\
\hline iNOS & Inducible nitric oxide synthase \\
\hline IVD & Intervertebral disc \\
\hline JNK & Jun NH2-terminal kinase \\
\hline LPS & Lipopolysaccharide \\
\hline MAPK & Mitogen-activated protein kinase \\
\hline MCP-1 & Monocyte chemotactic protein-1 \\
\hline MKK & MAPK kinase \\
\hline MMP & Matrix metalloproteinase \\
\hline NBD & NEMO binding domain \\
\hline NEMO & $N F-\kappa B$ essential modulator \\
\hline NF & Nuclear factor \\
\hline NGF & Nerve growth factor \\
\hline NO & Nitric oxide \\
\hline NP & Nucleus pulposus \\
\hline ODN & Naked decoy oligonucleotide \\
\hline p75NTR & p75 neurotrophin receptor \\
\hline PDGF & Platelet-derived growth factor \\
\hline PGE & Prostaglandin E \\
\hline PI3K & Phosphatidylinositol 3-kinase \\
\hline PKC & Protein kinase $\mathrm{C}$ \\
\hline RHD & Rel homology domain \\
\hline TGF & Transforming growth factor \\
\hline TIMP & Tissue inhibitor of metalloproteinases \\
\hline TNF & Tumor necrosis factor \\
\hline TonEBP & Tonicity-responsive enhancer binding protein \\
\hline TSLP & Thymic stromal lymphopoietin \\
\hline TWEAK & Tumor necrosis like weak inducer of apoptosis \\
\hline VEGF & Vascular endothelial growth factor \\
\hline
\end{tabular}

\section{Introduction}

Degeneration of the intervertebral disc (IVD) is a normal part of the ageing process, and is typically characterised 
by a loss of disc extracellular matrix. This loss is due to perturbed matrix homeostasis, whereby matrix anabolism is decreased and matrix catabolism is increased. Aging is associated with increased cellular senescence and changes in disc cellular phenotype that result in cells with decreased matrix synthesis capacity and/or altered matrix production. Additionally, enzymes mediating matrix degradation, including matrix metalloproteinases (MMPs), are up-regulated during the process of IVD degeneration and aging, resulting in increased matrix degradation (Cui et al., 2010; Roberts et al., 2000; Weiler et al., 2002). Consequently, loss and remodelling of the extracellular matrix (ECM) can lead to the occurrence of clefts and tears and eventually complete disc structural failure.

Despite the large structural changes in their discs, patients with IVD degeneration often remain symptomfree. Nevertheless, a subgroup of individuals with IVD degeneration experience pain and thus can be categorised to have intervertebral disc disease (IDD). A recent systematic review indicated that the odds of chronic low back pain given the presence of disc degeneration (detected by magnetic resonance imaging changes) ranged from 1.8 to 2.8 , meaning that the chances of suffering from back pain in people with degenerated discs was 2-3 times higher than in individuals without degenerated discs (Chou et al., 2011). Important in the context of disc-related back pain is the observed phenomenon of innervation of sensory nerve fibres in degenerated discs. These sensory nerves, containing nociception-related mediators such as substance $\mathrm{P}$ or calcitonin can penetrate not only into the peripheral annulus fibrosus (AF), but also into deeper zones of degenerated discs, especially if radial fissures and reduced pressure in the nucleus pulposus are present, (Adams et al., 1996; Freemont et al., 1997; Hastreiter et al., 2001; Ozawa et al., 2006; Peng et al., 2006; Peng et al., 2005). Irritation of these sensory nerves has been described as a major underlying mechanism of discogenic back pain, which may occur via inflammatory processes (Goupille et al., 2007; Olmarker and Rydevik, 1998). Recently, surgically-removed human degenerative discs were shown to be actively inflammatory (Adams et al., 2010). Past research has also provided evidence that IDD is correlated to increased levels of pro-inflammatory cytokines in disc tissue, such as interleukin $1 \beta$ (IL-1 $\beta$ ), interleukin 6 (IL-6), interleukin 8 (IL-8) and tumor necrosis factor $\alpha$ (TNF- $\alpha$ ): LeMaitre et al. (2007) demonstrated that herniated discs and degenerated discs from patients with chronic back pain showed higher expression of IL- $1 \beta$ and TNF- $\alpha$ than non-degenerated discs derived from post-mortem tissue from people without a history of back pain. In fact, not only IL- $1 \beta$, but also IL- $1 \alpha$, type-I receptor of IL- 1 and the IL-1 $\beta$-converting enzyme were present in higher levels in degenerated samples compared to non-degenerated ones (Le Maitre et al., 2005). Furthermore, TNF- $\alpha$ expression increased continuously with age in the $\mathrm{AF}$ and up to the age of 60 years in the nucleus pulposus (NP) in a population study consisting of autopsy samples that did not have any medical notes concerning relevant back problems (Bachmeier et al., 2007). Importantly, surgical samples from patients with a low back pain history (protrusion, herniation, degenerative disc disease) showed higher level of TNF- $\alpha$ positively labelled cells than the autopsy group (Bachmeier et al., 2007). Similarly, Weiler et al. (2005) demonstrated that surgical disc tissue from symptomatic back pain patients contained more TNF- $\alpha$ positive cells than asymptomatic autopsy samples, with a positive correlation to the degree of degeneration for the AF. Burke et al. (2002) clearly demonstrated that disc tissue from patients with discogenic back pain revealed higher protein levels of IL-6 and IL-8 than patients with sciatica. A most recent immunohistochemical comparison of surgical disc tissue (degenerative disc disease, disc herniation) and non-degenerated autopsy discs showed higher expression of IL-4, IL-6 and IL-12 in surgical samples than in autopsy samples, but with highest levels in the cases of disc herniation (Shamji et al., 2010). In summary, these studies indicate that the inflammatory mediators play an important role in the processes of IDD and possibly IDDrelated back pain.

During the past years, gene expression and function of these mediators in IDD have been a major topic of research interest. Furthermore, extensive therapeutic studies in the field of osteoarthritis and rheumatoid arthritis have highlighted the need to identify the underlying signalling pathways, prompting scores of IVD researchers to explore the molecular mechanisms leading to IVD inflammation and catabolism. This review describes two major intracellular pathways, nuclear factor kappa B (NF- $\mathrm{B}$ ) and mitogenactivated protein kinases (MAPKs), which potentially play vital roles in mediating the molecular events responsible for the initiation and progression of IDD. A graphical illustration of the NF- $\mathrm{\kappa B}$ and MAP kinase pathways (as described in this review paper) is given in Fig. 1. Although this review focuses primarily on the NF- $\kappa \mathrm{B}$ and MAPK pathways, the reader should keep in mind that the final effect of the activation of signalling pathways depends on their "crosstalk" with other activated pathways. For instance, a pathway that crosstalks with both the MAPK and the NF- $\kappa$ B pathways is the phosphatidylinositol 3-kinase (PI3K)/Akt axis (Conejo et al., 2002; Koh et al., 2006), which also seems to be involved in IVD homeostasis, e.g. by regulating aggrecan expression, glycosaminoglycan deposition and cell survival (Cheng et al., 2009; Risbud et al., 2005b).

\section{Transcription Factor NF- $\kappa \mathbf{B}$}

$\mathrm{NF}-\kappa \mathrm{B}$ is a central component in the cellular response to damage, stress and inflammation. NF- $\kappa \mathrm{B}$ was first described in 1986 in B-lymphocytes and acquired its name as it was found in the nucleus where it bound to an enhancer element of the immunoglobulin kappa light chain gene (Sen and Baltimore, 1986). NF- $\mathrm{BB}$ proteins comprise a family of structurally related "rapid-acting" transcription factors, all sharing a common highly conserved 300-amino acid region, the Rel homology domain (RHD). In mammals, the ubiquitously expressed NF- $\kappa \mathrm{B}$ family consists of five protein subunits, RelA or p65, c-Rel, RelB, p50 and p52. $\mathrm{NF}-\kappa \mathrm{B}$ exists either as a homodimer or a heterodimer, the most abundant being the p50-p65 heterodimer, which controls the expression of the majority of NF- $\kappa \mathrm{B}$-regulated genes (Baeuerle and Henkel, 1994). 


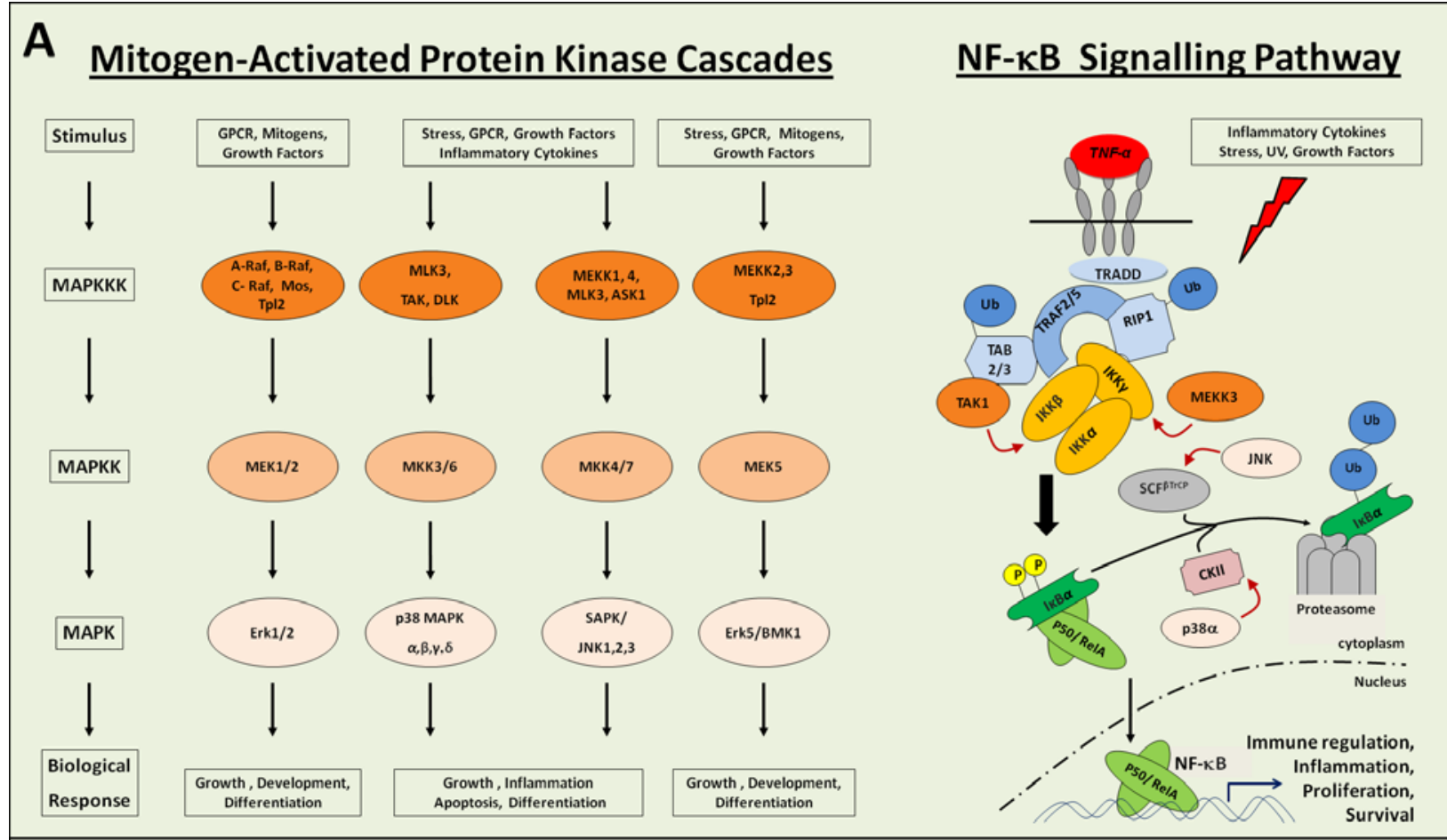

\section{B $\quad$ MAPK signalling in disc}

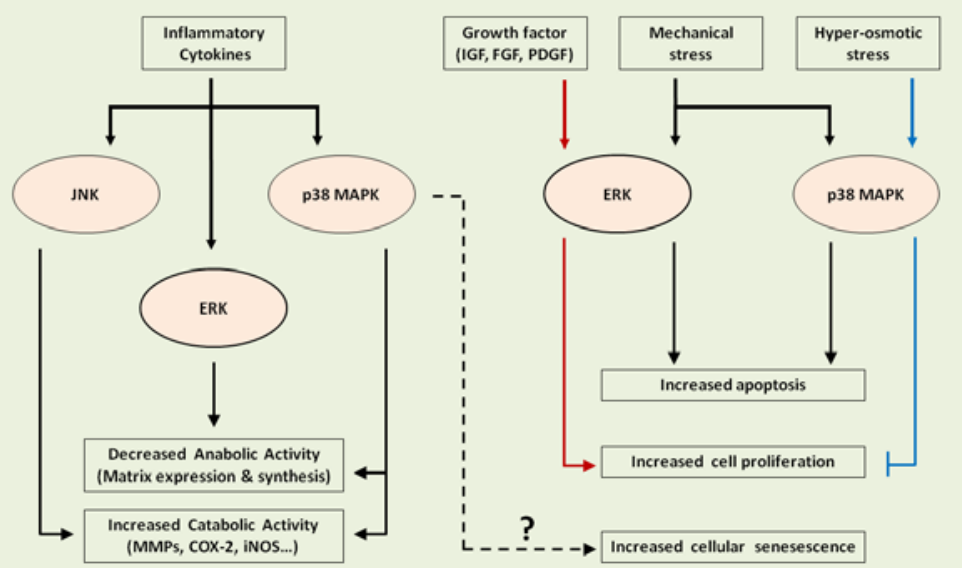

\section{$\underline{\text { NF- } \mathrm{KB} \text { signalling in disc }}$}

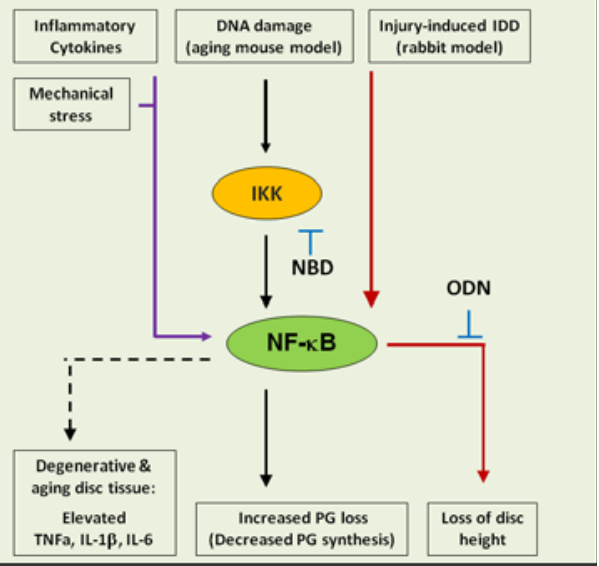

Fig. 1. MAPK and NF- $\kappa B$ pathways. (A) Canonical cascades of the MAP kinases and NF- $\kappa B$ signalling pathway (Hacker and Karin, 2006; Roux and Blenis, 2004). Left panel: Representative modules of the pathway connections for the respective MAPK phosphorelay systems. The complexity of the system is evident in the multiple stimuli leading to various biological responses through the multi-component levels of MAKKKs, MAKKs, and MAPKs. Right panel: Representative modules in the canonical NF- $\kappa B$ signalling. Specific cross talks between the components of MAPK and NF- $\mathrm{KB}$ pathways are included (red arrows). (B) Current reported literature of involvement of MAPK and NF- $\kappa$ B pathways in intervertebral discs. Left panel: Involvement of the MAPK signalling in disc metabolism. Inflammatory stress perturbs disc matrix homeostasis through the ERK, p38, and JNK-mediated pathways, while both ERK and p38 are reported to mediate stimuli from mechanical stress and growth factors on disc cell apoptosis and senescence. Elevated in degenerated discs, cellular senescence might be mediated by p38 in disc cells (dashed line) as activation of $\mathrm{p} 38 \mathrm{a}$ is required for stress-induced cellular senescence in other cell types (Freund et al., 2010).

Right panel: Involvement of the NF- $\mathrm{KB}$ signalling in disc metabolism. Inflammatory and mechanical stress are known to activate NF- $\kappa \mathrm{B}$ in disc cells, leading to expression of key catabolic factors such as MMPs. Elevation of NF- $\kappa \mathrm{B}$ is also reported in an accelerated aging mouse model due to DNA repair deficiency as well as in the injury-induced IDD rabbit model, both of which correlate to disc matrix loss. In animal studies, blocking NF- $\kappa$ B activity using the $\mathrm{NF}-\kappa \mathrm{B}$ decoy ODN proved effective in partially restoring IVD height in a rabbit model of IDD induced by annular puncture (Akeda et al., 2005), or NBD (nemo binding domain) peptide which inhibits IKK formation ameliorates age-related disc matrix loss in the progeroid mouse model (Nasto et al., 2011). Consistent with these findings are reports of increased NF- $\mathrm{KB}$ activation and activity in aged and degenerated disc. 
Table 1: Summary of target genes of NF-אB and MAPK in IVD cells.

\begin{tabular}{|c|c|c|c|c|}
\hline Gene & Signalling Pathway & Species & Reference & Gene Function \\
\hline ADAMTS4 & $\mathrm{NF}-\kappa \mathrm{B}$ & Human & (Wang et al., 2012) & Matrix degrading enzyme \\
\hline ADAMTS5 & $\mathrm{NF}-\kappa \mathrm{B}$ & Human & (Wang et al., 2012) & Matrix degrading enzyme \\
\hline Aggrecan & $\begin{array}{l}\text { p38 } \\
\text { ERK } \\
\end{array}$ & $\begin{array}{l}\text { Rabbit } \\
\text { Bovine } \\
\text { Bovine }\end{array}$ & $\begin{array}{l}\text { (Studer et al., 2008) } \\
\text { (Kim et al., 2012) } \\
\text { (Kim et al., 2012) }\end{array}$ & Matrix protein \\
\hline ASIC3 & ERK & Rat & (Uchiyama et al., 2007) & Ion channel \\
\hline Collagen I & p38 & Rabbit & (Studer et al., 2008) & Matrix protein \\
\hline Collagen II & ERK & Human & (Xia and Zhu, 2010) & Matrix protein \\
\hline COX-2 & p38 & Rabbit & (Studer et al., 2008) & Prostaglandin biosynthesis \\
\hline IGF-1 & p38 & Rabbit & (Studer et al., 2008) & Growth factor \\
\hline IL-6 & p38 & $\begin{array}{l}\text { Human } \\
\text { Rabbit }\end{array}$ & $\begin{array}{l}\text { (Kim et al., 2009) } \\
\text { (Studer et al., 2008) }\end{array}$ & Cytokine \\
\hline IL-8 & $\mathrm{p} 38$ & Human & (Kim et al., 2009) & Cytokine \\
\hline iNOS & $\begin{array}{l}\mathrm{p} 38 \\
\text { ERK }\end{array}$ & $\begin{array}{l}\text { Bovine } \\
\text { Bovine }\end{array}$ & $\begin{array}{l}\text { (Kim et al., 2012) } \\
\text { (Kim et al., 2012) }\end{array}$ & NO biosynthesis \\
\hline MCP-1 & $\mathrm{NF}-\kappa \mathrm{B}$ & Mouse & (Wako et al., 2008) & Cytokine \\
\hline MMP1 & $\begin{array}{l}\text { NF-кB } \\
\text { p38 } \\
\text { JNK }\end{array}$ & $\begin{array}{l}\text { Human } \\
\text { Bovine } \\
\text { Bovine }\end{array}$ & $\begin{array}{l}\text { (Pichika et al., 2005) } \\
\text { (Seguin et al., 2006) } \\
\text { (Seguin et al., 2006) }\end{array}$ & Matrix degrading enzyme \\
\hline MMP2 & $\begin{array}{l}\text { NF- } \kappa B \\
\text { ERK }\end{array}$ & $\begin{array}{l}\text { Human } \\
\text { Bovine }\end{array}$ & $\begin{array}{l}\text { (Pichika et al., 2005) } \\
\text { (Seguin et al., 2008) }\end{array}$ & Matrix degrading enzyme \\
\hline MMP3 & $\begin{array}{l}\text { NF-kB } \\
\text { p38 } \\
\text { JNK }\end{array}$ & $\begin{array}{l}\text { Human } \\
\text { Bovine } \\
\text { Rabbit } \\
\text { Bovine } \\
\text { Mouse }\end{array}$ & $\begin{array}{l}\text { (Pichika et al., 2005) } \\
\text { (Seguin et al., 2006) } \\
\text { (Studer et al., 2008) } \\
\text { (Seguin et al., 2006) } \\
\text { (Wako et al., 2008) }\end{array}$ & Matrix degrading enzyme \\
\hline MMP9 & 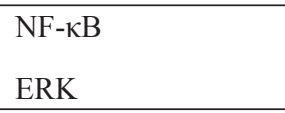 & $\begin{array}{l}\text { Human } \\
\text { Human }\end{array}$ & $\begin{array}{l}\text { (Pichika et al., 2005) } \\
\text { (Xia and Zhu, 2010) }\end{array}$ & Matrix degrading enzyme \\
\hline MMP13 & $\begin{array}{l}\text { NF-kB } \\
\text { p38 } \\
\text { ERK } \\
\text { JNK } \\
\end{array}$ & $\begin{array}{l}\text { Human } \\
\text { Bovine } \\
\text { Human } \\
\text { Bovine } \\
\end{array}$ & $\begin{array}{l}\text { (Pichika et al., 2005) } \\
\text { (Seguin et al., 2006) } \\
\text { (Xia and Zhu, 2010) } \\
\text { (Seguin et al., 2006) }\end{array}$ & Matrix degrading enzyme \\
\hline MMP14 & ERK & Bovine & (Seguin et al., 2006) & Matrix degrading enzyme \\
\hline SOX-9 & ERK & Bovine & (Kim et al., 2012) & Transcription factor \\
\hline TGF- $\beta 1$ & p38 & Rabbit & (Studer et al., 2008) & Growth factor \\
\hline TIMP-1 & $\begin{array}{l}\mathrm{p} 38 \\
\text { ERK }\end{array}$ & $\begin{array}{l}\text { Rabbit } \\
\text { Bovine }\end{array}$ & $\begin{array}{l}\text { (Studer et al., 2008) } \\
\text { (Kim et al., 2012) }\end{array}$ & Inhibitor of MMPs \\
\hline TIMP-2 & ERK & $\begin{array}{l}\text { Rabbit } \\
\text { Bovine } \\
\text { Bovine } \\
\end{array}$ & $\begin{array}{l}\text { (Studer et al., 2008) } \\
\text { (Kim et al., 2012) } \\
\text { (Kim et al., 2012) }\end{array}$ & Inhibitor of MMPs \\
\hline
\end{tabular}

The transcription activity of NF- $\kappa \mathrm{B}$ is tightly controlled by binding of inhibitor of NF- $\kappa \mathrm{B}(\mathrm{I} \kappa \mathrm{B})$ proteins, resulting in sequestration of NF- $\kappa \mathrm{B}$ in the cytoplasm. Depending on I $\kappa \mathrm{B}$ modification, the $\mathrm{NF}-\kappa \mathrm{B} / \mathrm{I} \kappa \mathrm{B}$ complex can either be retained in the cytoplasm or can be a constantly shuttled between cytoplasm and nucleus, but with a balance that is largely shifted towards nuclear export rather than import (Web ref. 1). Canonical activation of NF- $\mathrm{BB}$ is mediated by IאB kinase (IKK), a heterotrimer consisting of two catalytic subunits, IKK $\alpha$ and IKK $\beta$, and a regulatory subunit termed IKK $\gamma$ or NEMO (NF- $\kappa \mathrm{B}$ essential modulator). In response to a variety of stimuli, including pro-inflammatory cytokines, pathogens, cellular stress, mechanical stress, radiation, and growth factors, IKK becomes activated and phosphorylates $\mathrm{I} \kappa \mathrm{B}$ at two specific serine residues (S32 and S36), leading to its ubiquitination and subsequent 
proteosomal degradation (Bubici et al., 2006; Hacker and Karin, 2006; Hayden and Ghosh, 2008; Karin and BenNeriah, 2000; Ramana et al., 2004). IкB degradation allows $\mathrm{NF}-\kappa \mathrm{B}$ to translocate to the nucleus where it selectively binds to its cognate DNA consensus sequence, as well as co-activators such as Creb-binding protein (CPB)/p300, to induce gene expression (Furia et al., 2002). Stress-induced activation of NF- $\kappa \mathrm{B}$ leads to secretion of inflammatory cytokines, increased expression of genes that regulate cell survival and growth, such as arrested proliferation or cell death, depending on the nature of the insult and extent of damage (Karin and Lin, 2002).

As NF- $\kappa$ B also activates expression of I $\kappa$ B itself, NF$\kappa \mathrm{B}$ activation is normally transient due to this negative feedback mechanism, lasting approximately 30-60 min in most cell types (Ghosh et al., 1998). However, this is only true for normal cells, whereas constitutive NF- $\mathrm{BB}$ activation could be observed in tumour cells (Sethi et al., 2008). Additionally, NF- $\kappa \mathrm{B}$ regulation also takes place in the nucleus via acetylation or phosphorylation, which modulate its transcriptional activity (Ghosh and Karin, 2002). More than 150 genes are regulated by NF- $\kappa \mathrm{B}$, including several proinflammatory mediators such as TNF- $\alpha$, IL-1 $\beta$, IL-6, cyclooxygenase-2 (COX-2), MMPs and adhesion molecules (Barnes and Karin, 1997; May and Ghosh, 1998).

\section{Role of Chronic Activation of NF- $\kappa \mathrm{B}$ in Diseases}

$\mathrm{NF}-\kappa \mathrm{B}$ is activated in response to numerous types of stress, including oxidative (Bubici et al., 2006), genotoxic (Wu et al., 2006), physical (Chen et al., 2001) and inflammatory stress (Web ref. 2), that have been implicated in the pathogenesis of many diseases. Indeed, chronic activation of NF- $\kappa \mathrm{B}$ is associated with numerous diseases, including musculo-skeletal diseases such as osteoarthritis (Berenbaum, 2004; Marcu et al., 2010), osteoporosis (Kim et al., 2006), rheumatoid arthritis (Dai et al., 2004), and muscular dystrophy (Acharyya et al., 2007). For instance, expression of MMP1, MMP3, and MMP13 in chondrocytes is mediated primarily by activated NF- $\mathrm{BB}$ (Elliott et al., 2002; Liacini et al., 2003; Mengshol et al., 2000). In addition, activation of the NF- $\kappa \mathrm{B}$ pathway is required for IL-1 to inhibit the expression of SOX-9, a transcription factor involved in chondrocyte differentiation (Murakami et al., 2000). NF-kB signalling is found to be persistently elevated in immune cells and regenerative muscle fibres of patients with Duchenne muscular dystrophy, the disorder associated with dystrophin deficiency that results in chronic inflammation and severe skeletal muscle degeneration (Acharyya et al., 2007). Oxidative stress-induced osteoclastogenesis in osteoporosis is also mediated by NF- $\kappa \mathrm{B}$ signalling (Altindag et al., 2008).

Overexpression of either the c-rel or p65/RelA subunit of NF- $\kappa$ B induces hallmark features of cellular senescence including decreased proliferation and morphologic changes, such as enlarged, multinucleated cells (Bernard et al., 2004; Bernard et al., 2001; Seitz et al., 2000). Moreover, $\mathrm{NF}-\kappa \mathrm{B}$ is up-regulated in tissues of aged rodents, specifically in the skin, liver, kidney, cerebellum, cardiac muscle and gastric mucosa (Bregegere et al., 2006; Giardina and Hubbard, 2002; Helenius et al., 1996a; Helenius et al., 1996b; Korhonen et al., 1997; Xiao and Majumdar, 2000). Cells derived from elderly persons and patients with Hutchinson-Gilford progeria, a disease of dramatically accelerated aging, also exhibited increased NF- $\kappa \mathrm{B}$ signalling (Adler et al., 2007; Boland, 2001; Kriete et al., 2008). Growing evidence indicates that NF- $\kappa$ B becomes activated in aged tissues in response to accumulated damage and mediates the degenerative changes. Indeed, a recent modelling study identified NF- $\kappa \mathrm{B}$ as the transcription factor most associated with mammalian aging, and demonstrated that expression of a subset of NF- $\kappa \mathrm{B}$ effectors is increased with aging (Adler et al., 2007). The role of NF- $\mathrm{BB}$ in aging is supported by the fact that genetic inhibition of NF- $\kappa B$ in skin reversed histological features of aging and signs of cellular senescence (Adler et al., 2007).

\section{Current Knowledge on the Role of NF- $\kappa$ B in the IVD}

\section{Role of NF- $\mathrm{NB}$ in IDD}

While NF- $\kappa$ B is implicated in a large number of diseases, only limited information of its role in IDD has been generated so far. Compared to asymptomatic autopsy disc samples, symptomatic (surgical) discs are characterised by increased levels of pro-inflammatory cytokines that are considered typical NF- $\kappa$ B target genes, e.g. TNF- $\alpha$, IL-1 $\beta$, IL-6 and IL-8 (Adams et al., 2010; Bachmeier et al., 2007; Burke et al., 2002; Hoyland et al., 2008; Le Maitre et al., 2005; Le Maitre et al., 2007; Ulrich et al., 2007). It is therefore likely that NF- $\mathrm{BB}$ activation is involved in disc disease. In fact, evidence supporting the role of NF- $\kappa \mathrm{B}$ in the IVD has been generated by immunohistochemical studies, demonstrating that activation of the NF- $\mathrm{BB}$ signalling system occurs in the human IVD in vivo, especially in the nucleus pulposus tissue (Nerlich et al., 2007). Furthermore, $\mathrm{NF}-\kappa \mathrm{B}$ activity in the IVD was shown to correlate with accumulated oxidative stress and increase with age and degeneration (Nerlich et al., 2007). Using a rabbit annular puncture model, intra-discal injection of 'naked' NF- $\kappa B$ decoy oligonucleotides (ODN) proved effective in partially restoring IVD height, indicating that activation of $\mathrm{NF}-\kappa \mathrm{B}$ is involved in matrix loss in this animal model of IDD

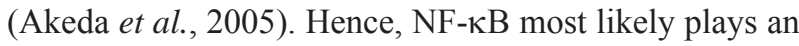
important mediatory role in the disc degenerative process. However, further investigation is needed to confirm if NF$\kappa \mathrm{B}$ is also involved in the development of a painful disc, as increased NF- $\kappa \mathrm{B}$ activity is found in both symptomatic and non-symptomatic degenerative discs.

\section{Target genes}

Although more than $150 \mathrm{NF}-\kappa \mathrm{B}-$ responsive genes have been identified in multiple cell types (Barnes and Karin, 1997; May and Ghosh, 1998), little is known about the gene targets of NF-кB in the IVD (Table 1). MMP1, MMP2, MMP3, MMP9 and MMP13 have been identified as NF- $\mathrm{B}$ target genes in IVD cells, as their protein levels are reduced by transfection of naked decoy oligonucleotides (ODN) into human IVD cells (Pichika et al., 2005). Furthermore, ADAMTS4 and ADAMTS5, the two major aggrecanases in the IVD, were most recently shown to be NF- $\kappa B$ dependent 


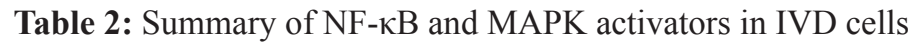

\begin{tabular}{|c|c|c|c|}
\hline Signalling Pathway & Activator & Species & Reference \\
\hline $\mathrm{NF}-\kappa \mathrm{B}$ & $\begin{array}{l}\text { IL-1 } \alpha \\
\text { IL-1 } \beta \\
\text { Peroxynitrite } \\
\text { TNF- } \alpha \\
\text { TNF- } \alpha \\
\text { TWEAK }\end{array}$ & $\begin{array}{l}\text { Human } \\
\text { Human } \\
\text { Human } \\
\text { Human } \\
\text { Murine } \\
\text { Mouse }\end{array}$ & $\begin{array}{l}\text { (Yu et al., 2009) } \\
\text { (Wuertz et al., 2011) } \\
\text { (Poveda et al., 2009) } \\
\text { (Oh et al., 2010) } \\
\text { (Wang et al., 2012) } \\
\text { (Ohba et al., 2009) } \\
\text { (Wako et al., 2008) }\end{array}$ \\
\hline p38 & $\begin{array}{l}\text { IL- } 1 \beta \\
\text { Lactoferricin } \\
\text { Osmolality } \uparrow \\
\text { Oxygen } \downarrow \\
\text { TGF- } \beta 1 \\
\text { TNF- } \alpha\end{array}$ & $\begin{array}{l}\text { Human } \\
\text { Bovine } \\
\text { Bovine } \\
\text { Rat } \\
\text { Bovine } \\
\text { Bovine }\end{array}$ & $\begin{array}{l}\text { (Wuertz et al., 2011) } \\
\text { (Kim et al., 2012) } \\
\text { (Mavrogonatou and Kletsas, 2009) } \\
\text { (Risbud et al., 2005b) } \\
\text { (Tsai et al., 2007b) } \\
\text { (Seguin et al., 2006) }\end{array}$ \\
\hline ERK & $\begin{array}{l}\text { bFGF } \\
\text { Fibronectin frag. } \\
\text { IGF-I } \\
\text { IL-1 } \beta \\
\text { Lactoferricin } \\
\text { NGF } \\
\text { Osmolality } \downarrow \\
\text { Osmolarity } \uparrow \\
\text { Oxygen } \downarrow \\
\text { PDGF } \\
\text { TGF- } \beta 1 \\
\text { TGF- } \beta 3 \\
\text { TNF- } \alpha\end{array}$ & $\begin{array}{l}\text { Bovine } \\
\text { Human } \\
\text { Bovine } \\
\text { Human } \\
\text { Bovine } \\
\text { Rat } \\
\text { Bovine } \\
\text { Rat } \\
\text { Rat } \\
\text { Bovine } \\
\text { Bovine } \\
\text { Rat } \\
\text { Bovine }\end{array}$ & $\begin{array}{l}\text { (Pratsinis and Kletsas, 2007) } \\
\text { (Xia and Zhu, 2010) } \\
\text { (Pratsinis and Kletsas, 2007) } \\
\text { (Wuertz et al., 2011) } \\
\text { (Kim et al., 2012) } \\
\text { (Uchiyama et al., 2007) } \\
\text { (Mavrogonatou and Kletsas, 2011) } \\
\text { (Tsai et al., 2007a) } \\
\text { (Risbud et al., 2005a; Risbud et al., 2005b) } \\
\text { (Pratsinis and Kletsas, 2007) } \\
\text { (Tsai et al., 2007b) } \\
\text { (Risbud et al., 2006) } \\
\text { (Seguin et al., 2006; Seguin et al., 2008) } \\
\end{array}$ \\
\hline JNK & $\begin{array}{l}\text { IL-1 } \beta \\
\text { Osmolality } \downarrow \\
\text { TNF- } \alpha \\
\text { TWEAK }\end{array}$ & $\begin{array}{l}\text { Human } \\
\text { Bovine } \\
\text { Bovine } \\
\text { Mouse }\end{array}$ & $\begin{array}{l}\text { (Wuertz et al., 2011) } \\
\text { (Mavrogonatou and Kletsas, 2011) } \\
\text { (Seguin et al., 2006) } \\
\text { (Wako et al., 2008) }\end{array}$ \\
\hline
\end{tabular}

(Wang et al., 2012). NF-кB inhibition study in mouse disc tissue stimulated with recombinant TNF- $\alpha$ in the presence or absence of chemical NF- $\mathrm{BB}$ inhibitors also identified vascular endothelial growth factor (VEGF) as a NF- $\kappa \mathrm{B}$ dependent disc gene (Ohba et al., 2009). The same group demonstrated that mRNA and protein expression of thymic stromal lymphopoietin (TSLP), which belongs to the cytokine family, is also regulated by the NF- $\kappa \mathrm{B}$ pathway in mouse IVD cells (Ohba et al., 2008). Furthermore, expression of monocyte chemoattractant protein-1 (MCP1), a chemotactic chemokine for macrophages, was shown to be regulated by the NF- $\mathrm{BB}$ pathway in mouse IVD cells (Wako et al., 2008).

\section{Activation}

Different exogenous and endogenous stimuli can activate NF- $\kappa$ B in the IVD (Table 2). Stimulation of human disc cells with recombinant IL-1 $\beta$ caused nuclear translocation of p65 into the nucleus, as confirmed by immunoblotting and immunocytochemistry as well as by electrophoretic mobility shift analysis (EMSA) (Wuertz et al., 2011). Stimulation of human IVD cells with IL-1 $\alpha$ also resulted in activation of NF- $\mathrm{BB}$ (detected by EMSA), even after 3 days (Yu et al., 2009). Similarly, TNF- $\alpha$ can also induce nuclear translocation of NF- $\kappa \mathrm{B}$ in human IVD cells (Oh et al., 2010; Wang et al., 2012), but our own data indicate that this effect is less persistent compared to IL-1 $\beta$ (Fig. 2 ). TNF- $\alpha$-induced activation of NF- $\kappa$ B was also shown in murine disc tissue (Ohba et al., 2009). Similarly, tumour necrosis factor-like weak inducer of apoptosis (TWEAK) was also shown to induce NF- $\kappa$ B activation in mouse IVD tissue (Wako et al., 2008). In contrast, LPS treatment did not (or only very slightly) cause nuclear translocation of p65 in human IVD cells (Fig. 2), even though this has been described for p65 in the literature for other cell and tissue types (Crisostomo et al., 2008; Deshpande et al., 1997; Rodrigues et al., 2008).

Furthermore, it was shown that peroxynitrite, one of the most damaging reactive oxygen species, was able to induce mRNA levels of IL-1 $\beta$, IL- 6 and IL- 8 in human IVD cells and this was correlated with sustained nuclear translocation of $\mathrm{p} 65$. However, as no inhibition experiments or knockdown experiments were performed, the causal relationship between the peroxynitrite-induced NF- $\kappa \mathrm{B}$ activation and the alterations of these mRNAs can only be assumed (Poveda et al., 2009). Depending on the type and magnitude of loading, mechanical signals have been shown to either activate or inhibit the NF- $\kappa$ B pathway in 
A

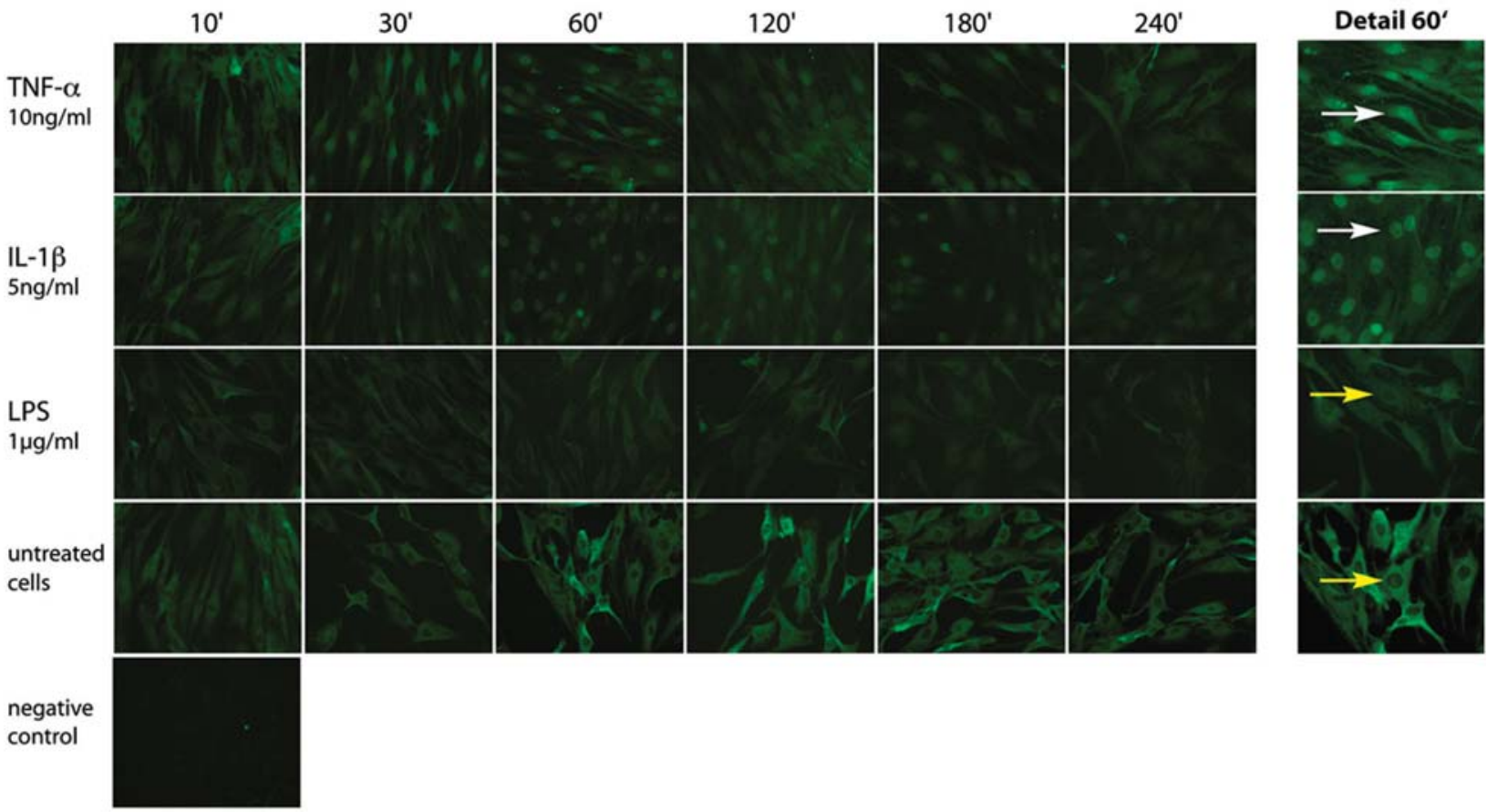

B

p65
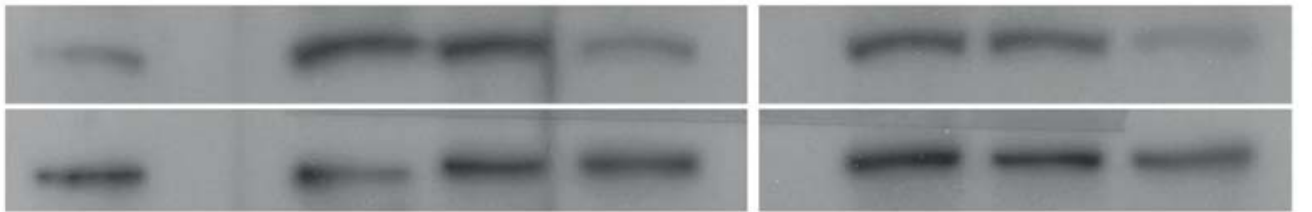

$60 \mathrm{kDa}$

PARP
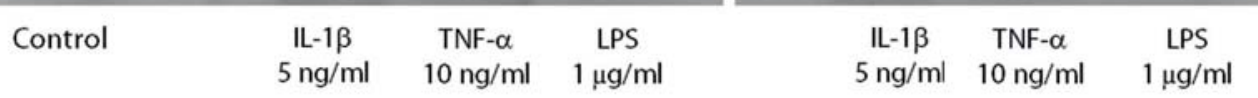

$116 \mathrm{kDa}$

Fig. 2. Time-dependent activation of NF- $\kappa B$ in human IVD cells after stimulation with TNF- $\alpha(10 \mathrm{ng} / \mathrm{mL}), \mathrm{IL}-1 \beta(5$ $\mathrm{ng} / \mathrm{mL})$ or LPS $(1 \mu \mathrm{g} / \mathrm{mL})$ was tested by (A) immunocytochemistry for p65 (after 10, 30, 60, 120, 180 and $240 \mathrm{~min}$ ) and (B) immunoblotting for p65 in nuclear extracts (30 min: left side, 60 min: right side). For detection of p65, a specific NF- $\kappa \mathrm{B} / \mathrm{p} 65$ antibody from Santa Cruz was used (sc-372). White arrows indicate nuclear translocation and yellow arrows indicate cytoplasmic location. Negative controls for immunocytochemistry were exposed to the secondary antibody (CY2), but not to the primary p65 antibody. PARP was used as a loading control for immunoblotting.

chondrocytes (Agarwal et al., 2003; Deschner et al., 2003). Similarly, hypoxia has been reported to enhance NF- $\mathrm{BB}$ activity (primarily through the canonical pathway) in low oxygen tissues, but no data is currently available with regard to the IVD (Oliver et al., 2009).

\section{Inhibition/Therapy}

Suppression of NF-kB has become a major research target to treat diseases in the past years. Different strategies to block NF- $\kappa \mathrm{B}$ have been investigated, such as the use of proteasome inhibitors, which may inhibit degradation of IкB upon phosphorylation and ubiquitination (Ahn et al., 2007; Palombella et al., 1994). Other possibilities may be to block IKK, the upstream regulator that phosphorylates I $\mathrm{B}$ (Ji et al., 2001), or to modify I $\mathrm{B}$ at the phosporylation or ubiquitination sites via gene transfer (Abu-Amer et al., 2001). In addition, a large group of anti-inflammatory drugs seem to have the potential to inhibit NF-кB. On the one hand, there are several traditional drugs that have been commonly used for decades, such as acetylsalicylic acid, ibuprofen or glucocorticoids, e.g. dexamethasone, which have NF- $\kappa$ B inhibitory activities (Auphan et al., 1995; Kopp and Ghosh, 1994). Furthermore, more "modern" pharmaceuticals, such as the COX-2 inhibitor rofecoxib, can influence NF- $\kappa \mathrm{B}$ activity, e.g. in this case by inhibiting its DNA binding capacity (Niederberger et al., 2003). On the other hand, there are multiple "natural" candidates that seem to inhibit NF- $\mathrm{BB}$ in certain cell types, such as resveratrol (a polyphenol found in wine) (Holmes-McNary and Baldwin, 2000), curcumin (the main component of curcuma) (Jobin et al., 1999; Surh et al., 2000) or capsaicin (found in red pepper) (Surh et al., 2000).

In human IVD cells, the well known anti-inflammatory steroid drug dexamethasone, which has been described to act as an inhibitor of NF- $\kappa \mathrm{B}$, was not able to inhibit the transcription of NF- $\kappa$ B stimulated by TNF- $\alpha$ in human IVD 


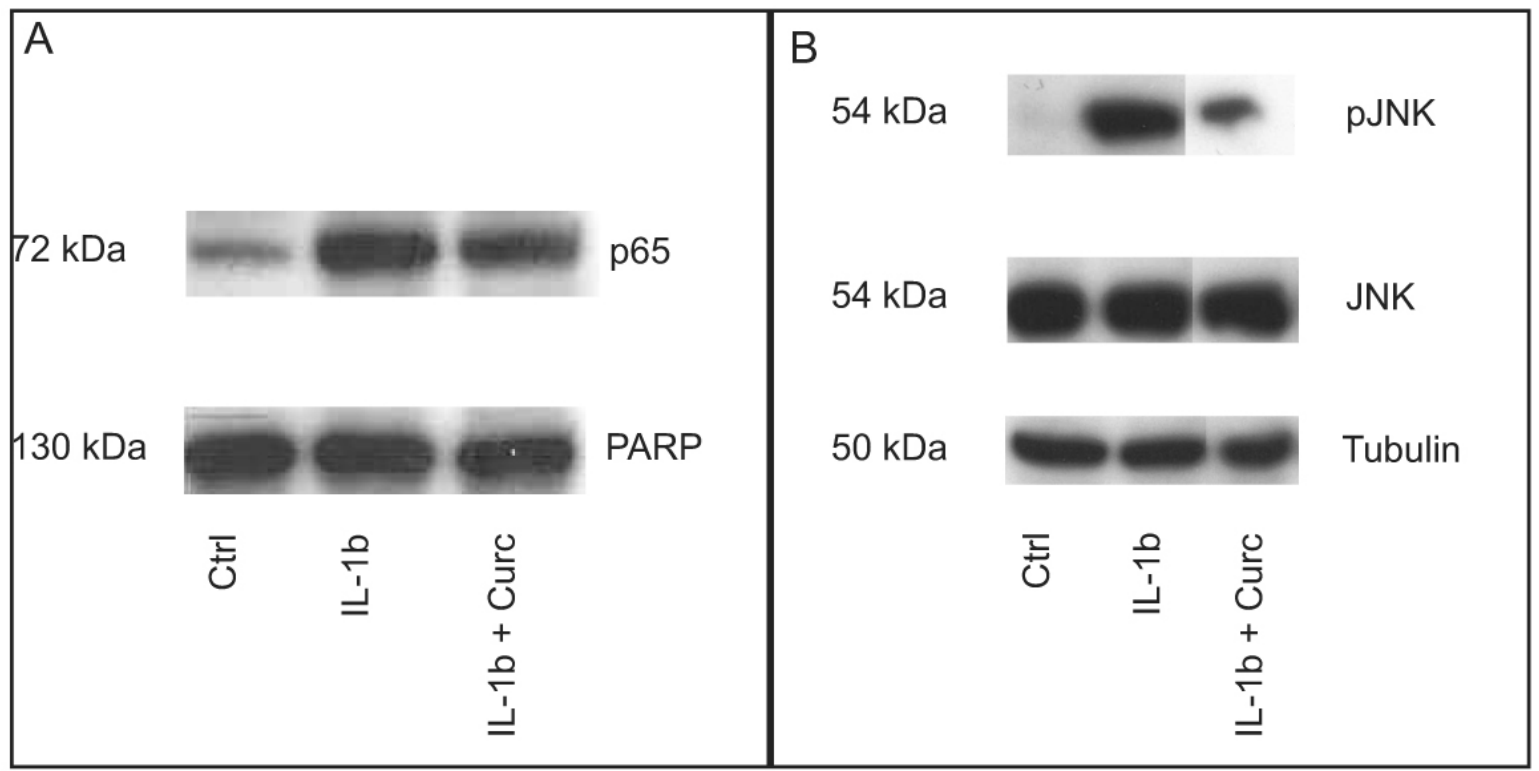

Fig. 3. Analysis on NF-kB (p65) and JNK activity after stimulation of human IVD cells with curcumin. Human IVD cells were treated with IL-1 $\beta$ to induce activation of (A) NF- $\kappa B$ (nuclear translocation of p65) and (B) JNK (phosphorylation) and co-treated with $20 \mu \mathrm{M}$ curcumin. Nuclear extracts (for NF- $\mathrm{BB} / \mathrm{p} 65$ ) or whole cell extracts (for JNK) were harvested after $30 \mathrm{~min}$ and $60 \mathrm{~min}$, respectively, and analysed by immunoblotting. While curcumin did not reduce nuclear translocation of p65 (compared to IL-1 $\beta$-treated samples), it was able to reduce phosphorylation of JNK (compared to IL-1 $\beta$-treated samples). Results for p65 and JNK of one representative donor are shown. Loading controls: PARP for p65, tubulin for JNK.

cells, as shown by the EMSA experiments (Oh et al., 2010). Similarly, the polyphenol resveratrol did not reverse IL-1 $\beta$ induced activation of NF- $\kappa \mathrm{B}$ as demonstrated by EMSA, immunoblotting and immunocytochemistry (Wuertz et al., 2011), although this has been described for chondrocytes (Shakibaei et al., 2008). Furthermore, the effect of resveratrol on insulin resistance and inflammatory mediators in obese and type 2 diabetic subjects is being investigated in a clinical trial (see http://clinicaltrials.gov).

Curcumin, a potential biological NF- $\kappa \mathrm{B}$ inhibitor, did not inhibit IL-1 $\beta$-induced activity of nuclear translocation of p65 at an early time point as shown in Fig. 3 (results not yet published), while late IL- $1 \alpha$-induced activity of NF- $\kappa B$ (after 3 days) was reduced when treated with curcumin ( $\mathrm{Yu}$ et al., 2009). As NF-кB is continuously shuttling between the nucleus and cytoplasm, assays measuring NF- $\kappa$ B activation by nuclear translocation (i.e. presence of p65 in the nucleus) can give variable results if the dose of inhibitor or time point of analysis are not optimally determined. It is also possible that the mechanisms of NF- $\mathrm{KB}$ activation and inhibition in disc cells are different from those found in other cell types. Hence, although time course experiments have been performed in most of the above-mentioned studies, a negative result cannot completely rule out inhibition of NF- $\kappa \mathrm{B}$ by the tested substances. Nevertheless, the failure of NF- $\kappa \mathrm{B}$ inhibition using well-established pharmaceuticals (e.g. dexamethasone) or natural substances at least challenges the efficacy of this therapeutic approach.

Aside from NF- $\kappa \mathrm{B}$ inhibition with "traditional substances" (as described above), another strategy that targets $\mathrm{NF}-\kappa \mathrm{B}$ has been investigated recently: NF- $\kappa \mathrm{B}$ decoy transduction into dorsal root ganglion neurons in vivo has been tested in a rat lumbar disc herniation model with regard to its efficacy in altering nerve injury, mechanical allodynia and thermal hyperalgesia. This strategy reduced nerve injury, improved mechanical allodynia and thermal hyperalgesia in this animal model (Suzuki et al., 2009) and may thus be a promising new approach but one that will require more detailed investigations in the future. A recent study revealed that systemic inhibition of $\mathrm{NF}-\kappa \mathrm{B}$ activation by the inducible IKK via chronic administration of the Nemo Binding Domain peptide inhibitor, 8K-NBD, in a mouse model of progeria $\left(E r c c 1^{-/ \Delta}\right.$ mice) delayed the onset of age-related IDD (Fig. 4) (Nasto et al., 2011). For adults with mild to moderate atopic dermatitis, the use of NF- $\kappa \mathrm{B}$ Decoy is being currently investigated in clinical trials (http://clinicaltrials.gov).

\section{MAPK Signalling Pathways}

MAPKs are a family of highly conserved signal transduction pathways, allowing the cells to respond to multiple extracellular inputs. MAPKs are activated by different stimuli, such as hormones and growth factors acting through tyrosine or serine/threonine kinases, inflammatory cytokines, peptides acting through $\mathrm{G}$ protein-coupled receptors, as well as environmental stresses such as ionising radiation or osmotic stress (Huang et al., 2010; Kyriakis and Avruch, 2001). In mammals, these diverse signals activate at least three major subfamilies of MAPKs, the extracellular signal-regulated kinases (ERK), c-Jun NH2terminal kinases (JNKs), and p38 isoforms (p38MAPKs) (Boutros et al., 2008; Wagner and Nebreda, 2009). All MAPKs are activated following a common cascading pat- 


\section{Untreated $\operatorname{Ercc1}-1 / \Delta$}

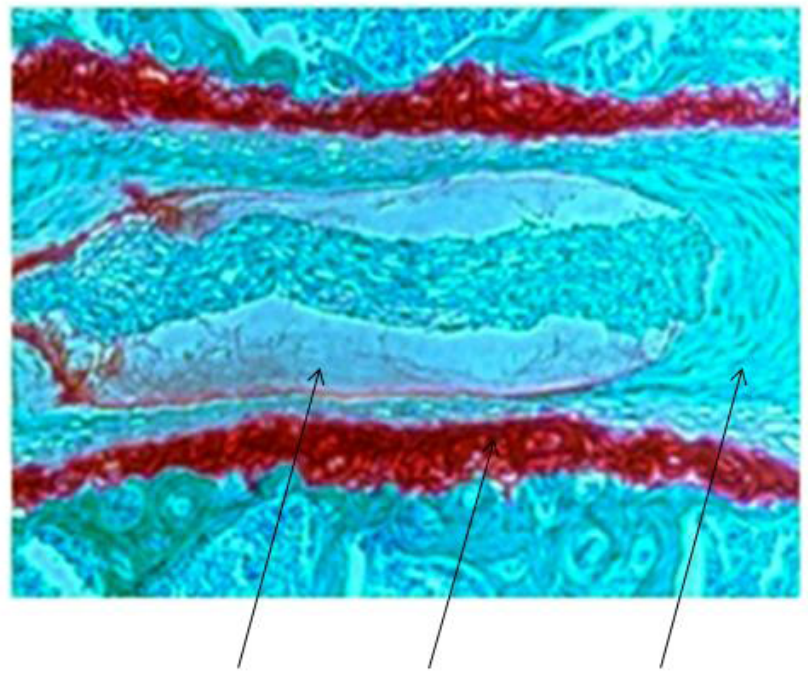

NP EP AF

\section{NBD-treated Ercc1 $1 / \Delta$}

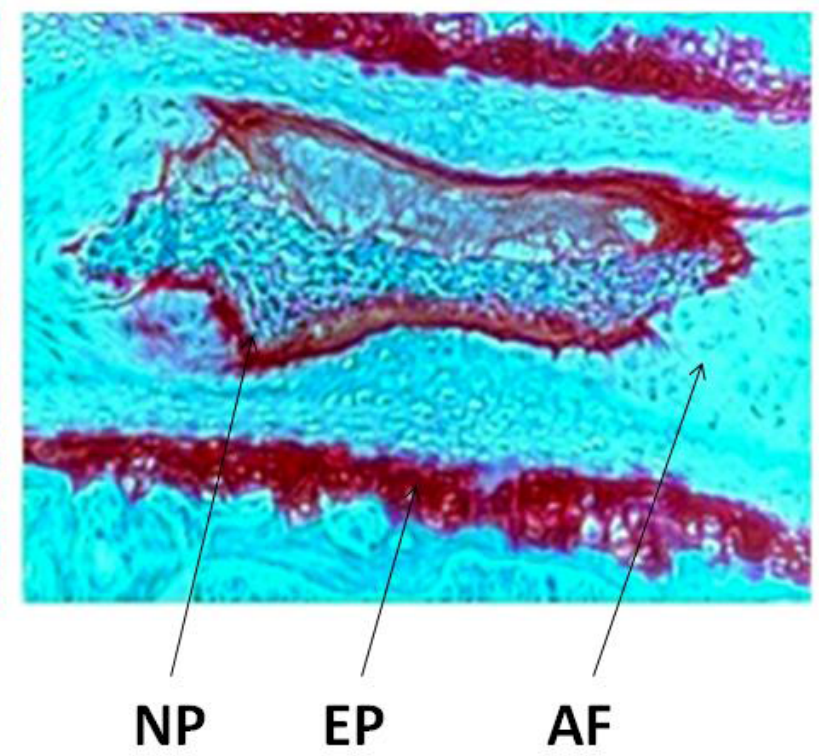

Fig. 4. Pharmacologic suppression of IKK/NF- $\kappa B$ activation ameliorates age-associated disc proteoglycan loss. Ercc1-/ $\Delta$ mice were treated with $10 \mathrm{mg}$ NBD per $\mathrm{kg}$ body weight three times per week intraperitoneally starting from 5 weeks of age until 20 weeks of age. Safranin $O$ histological staining of disc sections of NBD-treated Ercc1-/ $\Delta$ mice and untreated Ercc1-/ $\Delta$ mice. Endplate (EP), nucleus pulposus (NP), and annulus fibrosus (AF) are indicated. Red, Safranin O staining of proteoglycan. NBD treatment increased Safranin staining of NP of Ercc1-/ $\Delta$ mice compared to untreated mice.

tern, i.e. each member of the family of MAPK is activated by specific upstream kinases (MAPKK) through phosphorylation on threonine and tyrosine residues, while each MAPKK is activated by a MAPKK kinase (MAPKKK) by phosphorylation on serine or threonine residues (Imajo et al., 2006).

ERK $1 / 2$ was the first mammalian MAPK pathway to be identified. It is regulated by the activation of the GTPase Ras, which recruits MAPKKKs of the Raf family and activate the MEK1 and MEK2 MAPKKs, which in turn activate the ERKs by phosphorylation (Chambard et al., 2007; Kyriakis and Avruch, 2001). Activation of the ERK pathway was found to control several cellular functions, including cell cycle progression. This is achieved by ERK-mediated regulation of components of the cell cycle machinery, such as c-Myc, cyclin D1 and cyclin-dependent kinases that phosphorylate the retinoblastoma protein, leading to the release of the E2F transcription factors and thus allowing the transition from the G1 to the S phase of the cell cycle (Chambard et al., 2007). JNKs are activated by various exogenous stresses, which lead to phosphorylation of tyrosine and threonine residues by the upstream kinases MMK4 and MKK7. JNKs are involved in the regulation of cell proliferation and survival (Wagner and Nebreda, 2009). Finally, the p38 MAPK pathway is also activated by many diverse stresses, resulting in dual phosphorylation on its threonine and tyrosine residues by the upstream kinases MKK3/6. Activation of $\mathrm{p} 38 \mathrm{MAPK}$ is associated with cell growth and differentiation, cell death and inflammation (Kaminska, 2005; Kyriakis and Avruch, 2001; Pearson et al., 2001). There are four known isoforms expressed in mammalian cells, i.e. p38 $\alpha$, p38 $\beta$, p38 $\gamma$ and p38 $\delta$, and the first two are expressed in most tissues, while p38 $\gamma$ and p38 $\delta$ are exclusively found in muscle, skin and kidney cells (Han and Sun, 2007; Huang et al., 2010). Amongst the various stimuli activating p38 are inflammatory cytokines (e.g. interleukins and TNF- $\alpha$ ), pathogenic stimuli (such as LPS, staphylococcal peptidoglycan, enterotoxin B and herpes simplex virus I) (Kaminska, 2005), and UV and gamma radiation (Dent et al., 2003). A summary of the known MAPK cascades, including ERK5, which has not been investigated in the disc so far, is given in Fig. 1.

\section{Roles of MAPKs in Diseases}

As MAPKs are activated by several exogenous stimuli commonly found in inflammatory diseases, e.g. inflammatory cytokines and growth factors, pathogenic components, reactive oxygen species, etc., these signalling pathways are closely involved in diseases such as rheumatoid arthritis, psoriasis, inflammatory bowel disease, neurodegenerative diseases or cancer (Huang et al., 2010; Wagner and Nebreda, 2009; Zarubin and Han, 2005). Hence, MAPKs represent important targets for therapeutic interventions. In this context, several specific kinase inhibitors have been developed for the regulation of these pathways, with the aim to function as anti-inflammatory agents. A few compounds have been used in clinical trials. However, toxic side effects still represent a major obstacle (Huang et al., 2010; Kaminska, 2005), probably due to the pivotal roles of the MAPK pathways in normal cellular physiology. 
Cellular senescence, which is increased in aged and degenerated discs, is regulated by the MAPK pathways (Gruber et al., 2010; Gruber et al., 2007; Kletsas, 2009; Roberts et al., 2006). In several cell types, activation of p38 MAPK, for example, is used as a marker of senescence (Chen and Ames, 1994; Iwasa et al., 2003; Papadopoulou and Kletsas, 2011), while constitutive activation of p38 via MKK3 or MKK6 is reported to induce premature senescence via the upregulation of cyclin-dependent kinase inhibitors (Wang et al., 2002; Wu, 2004). In addition, the $\mathrm{MEK} / \mathrm{ERK}$ pathway is involved in the oncogenic Ras induced senescence (Lee et al., 1999; Maruyama et al., 2009), while JNK has been reported to inhibit or provoke cellular senescence under different settings (Maruyama et al., 2009).

\section{Current Knowledge on the Role of MAPKs in the IVD}

\section{Role of MAPKs in IDD}

MAP kinases have received greater attention in the IVD research community during the past few years. However, little information still exists on their expression and activity in relation to the progression of IDD. With laser capture microdissection (LCM) microarray, which can be used to identify cell-specific gene expression patterns, Gruber et al. (2010) provided evidence that p38 MAPK gene expression is upregulated in senescent human AF cells compared to non-senescent cells. Furthermore, in a rodent in vivo stab injury model, annular fibroblasts became immunopositive for the phosphorylated form of $\mathrm{p} 38$ and produced increased levels of proinflammatory factors, such as IL-1 and TNF- $\alpha$ (Ulrich et al., 2007).

The MAPK signalling pathways seem to play a crucial role in modulating both matrix synthesis and degradation in the IVD by altering expression of anabolic and catabolic genes, as well as by influencing proteoglycan degradation in the IVD. In particular, the p38 and ERK signalling pathways have been shown to play a role in proteoglycan metabolism, as treatment with chemical inhibitors of p38 or ERK significantly counteracted the cytokine-induced decrease in proteoglycan content, synthesis and release (Seguin et al., 2006; Studer et al., 2008). For the first time, ERK is recently reported to be involved in the activation of Wnt/b-catenin signals, which may contribute to the pathogenesis of IDD (Hiyama et al., 2011). Furthermore, activation of $\mathrm{p} 38$ by hyperosmotic conditions (as seen in the IVD during daily activity) has an inhibitory effect on cell proliferation via induction of a G2 arrest in bovine NP cells (Mavrogonatou and Kletsas, 2009). On the other hand, ERK activation plays an important role in cell adhesion by positively influencing $\alpha 2$-integrin expression, as well as cell adhesion to collagen II substrates in rat NP cells (Risbud et al., 2005b). In addition, activation of ERK and p38, which was shown to be higher in freshly isolated compared to expanded bovine IVD cells (Tsai et al., 2007b), can counteract apoptosis induced by mechanical stress (in the endplate (EP) and transitional zone of AF) (Ariga et al., 2003) or by serum starvation under hypoxic conditions (in the rat NP) (Risbud et al., 2005a). As mentioned above, several growth factors exert their mitogenic action by activating ERK by phosphorylation. On the other hand, several growth factors and growth factor receptors have been found to be over expressed in degenerated discs (Pratsinis and Kletsas, 2008). Likewise, classical growth factors such as platelet-derived growth factor (PDGF), insulin-like growth factor-I (IGF-I) or basic fibroblast growth factor (bFGF), which are known to be overexpressed in degenerated disc tissue, can stimulate ERK and subsequent DNA synthesis in bovine AF and NP cells in vitro (Pratsinis and Kletsas, 2007), indicating that MAPKs are possibly involved in catabolic and anabolic processes in the IVD.

\section{Target genes}

MMP9, MMP13, MMP14, inducible nitric oxide synthase (iNOS), tissue inhibitor of metalloproteinases (TIMP)-1, TIMP-2, TIMP-3, aggrecan, collagen II, SOX-9, acidsensing ion channel (ASIC) 3 and tonicity-responsive enhancer binding protein (TonEBP) all have been identified as target genes of ERK in IVD cells of various species (Kim et al., 2012; Seguin et al., 2006; Tsai et al., 2007a; Uchiyama et al., 2007; Xia and Zhu, 2010). Furthermore, the ERK pathway seems essential in regulating the enzymatic activation of MMP2 via early growth factor EG-1 (Seguin et al., 2008). The p38 pathway controls expression of MMP1, MMP3, MMP13, IL-6, IL-8, COX-2, iNOS, VEGF, IGF-1, transforming growth factor (TGF)- $\beta$ and TonEBP (Kim et al., 2009; Kim et al., 2012; Seguin et al., 2006; Studer et al., 2008; Tsai et al., 2007a) and influences levels of prostaglandin (PGE)2, PGF2 $\alpha$ and nitrite (Kim et al., 2009; Studer et al., 2008). Furthermore, expression of the anabolic and anti-catabolic genes aggrecan, collagen I, collagen II, versican, TIMP-1, TIMP-2 and TIMP-3 seems to be influenced by the p38 MAPK pathway as well (Kim et al., 2012; Studer et al., 2008). Finally, JNK was shown to regulate expression of MMP1, MMP3 and MMP13 (Seguin et al., 2006; Wako et al., 2008). All genes known to be regulated by MAPKs in disc cells are summarised in Table 1.

\section{Activation}

Several signalling molecules of MAPK pathways in IVD cells have been identified in the past years (Table 2). The proinflammatory cytokines TNF- $\alpha$ and IL- $1 \beta$ are able to induce activation of the ERK, p38 and JNK pathways in bovine, rabbit and human IVD cells (Klawitter et al., 2011; Seguin et al., 2006; Seguin et al., 2008; Studer et al., 2008; Wuertz et al., 2011). Treatment of rat IVD cells with nerve growth factor (NGF) resulted in a rapid increase in the levels of phosphorylated ERK, which was mediated through the low-affinity neurotrophin receptor (p75NTR) (Uchiyama et al., 2007). Furthermore, the fragmented form of the matrix protein fibronectin was shown to induce phosphorylation of ERK $1 / 2$ in a protein kinase C (PKC)-dependent manner (Xia and Zhu, 2010). Lactoferricin, a glycoprotein from the transferrin family, was also shown to activate the p38 and ERK signalling in bovine NP cells (Kim et al., 2011) and TGF- $\beta$-induced levels of phosphorylated ERK1/2 and p38 (Risbud et al., 
2006; Tsai et al., 2007b). JNK activation was shown to take place upon stimulation of mouse IVD tissue with TWEAK (Wako et al., 2008).

Other environmental factors also seem to play a crucial role in MAPK activation: hyperbaric oxygen for example reduced phosphorylation of p38 MAPK in human IVD cells (Niu et al., 2011). High osmolarity, to which NP cells are exposed during daily activities (Urban, 2002), resulted in p38 MAPK activation in bovine NP cells, while the activation of ERK and JNK was inhibited under these conditions (Mavrogonatou and Kletsas, 2009; Mavrogonatou and Kletsas, 2010; Mavrogonatou and Kletsas, 2011). Notably, this differential regulation of MAP kinases was observed after stimulation of cells with a salt solution $(\mathrm{NaCl} / \mathrm{KCl})$ or the osmolyte sorbitol but not by urea, indicating that these effects are due to changes in osmolality and not to increased ionic strength (Mavrogonatou and Kletsas, 2011). It is well known that one of the characteristics of the disc NP cells' environment is high osmolality due to the abundance of proteoglycans. This osmolality can increase further during daily activities, but it is decreased in the degenerated discs. These changes affect also growth factor-mediated ERK activation. In particular, while ERK activation is decreased under hyperosmotic conditions in bovine NP cells, its activation is enhanced in hypoosmotic conditions, indicating that the conditions of the degenerated disc are more permissive for cell proliferation and repair (Mavrogonatou and Kletsas, 2010). In contrast, in rat NP cells, hyperosmotic culture conditions induced by $\mathrm{NaCl}$ supplementation of the medium were shown to increase phosphorylation and activation of ERK (Tsai et al., 2007a). Furthermore, hypoxic conditions induced phosphorylation of both, p38 and ERK MAPK in rat NP cells (Risbud et al., 2005a; Risbud et al., 2005b). Cellular responses to microenvironmental factors, i.e. alteration in oxygen levels and osmotic pressure, are inherent mediatory steps in the degenerative processes of the IVD. Activation of MAPK signalling pathways by exogenous stresses seems to affect several aspects of IVD homeostasis. Hypoxic environment activates ERK leading to the upregulation of $\alpha 2$ integrin and to an increased cell survival in discs (Risbud et al., 2005b). In addition, hypoxia increases the expression of $\beta$-1,3-glucuronyltransferase 1 (GlucAT-1), a key enzyme in glucosaminoglycan synthesis, a process that is partly mediated by ERK activation (Gogate et al., 2011). Furthermore, hypertonicity activates ERK in rat NP cells, leading to the transactivation of TonEBP, a transcription factor that is involved in the adaptation to osmotic stress and in the regulation of aggrecan expression (Tsai et al., 2007a). This is in agreement with the effect of osmotic stress on aggrecan overexpression in chondrocytes (Peffers et al., 2010). Finally, exposure of disc cells to high osmolality decreased the phosphorylation of ERK in response to serum or to isolated growth factors, such as PDGF or IGF-I, thus inhibiting bovine NP cell proliferation (Mavrogonatou and Kletsas, 2010; Pratsinis and Kletsas, 2007).

\section{Inhibition/Therapy}

Inhibition of MAPK activity under inflammatory stressful conditions has been demonstrated to be potentially beneficial in treating IDD by stimulating matrix protein expression (aggrecan, collagen-I, collagen-II, versican) and by inhibiting expression of inflammatory mediators (IL-1 $\beta$, IL-6, COX-2, NO, PGE-2) and matrix degrading enzymes (MMP3) (Niu et al., 2011; Studer et al., 2008). So far, several chemical/biological therapeutics as well as external factors have been identified that can influence the activity of the specific MAPKs. While no clinical studies have been performed so far with regard to IDD, several MAPK inhibitors, especially p38 MAPK inhibitors, are currently being investigated for other inflammation-related diseases. For rheumatoid arthritis, the efficacy and safety of oral medication of the p38 MAP kinase inhibitors VX702, RO4402257 or PH-797804 are being determined in ongoing clinical studies (http://clinicaltrials.gov).

Phosphorylation (and thus activation) of p38 can be reduced by link $\mathrm{N}$ peptide (the $\mathrm{N}$-terminal peptide of link protein) (Petit et al., 2011) and triptolide (diterpenoid triepoxide form the Chinese herb, Tripterygium wilfordii Hook) (results not yet published) in human IVD cells, with an overall pro-anabolic, anti-catabolic and anti-inflammatory effect. Furthermore, triptolide also inhibited ERK activation, while curcumin (the principal curcuminoid in curcuma/tumeric) reduced activation of JNK in human disc cells (Fig. 3) (Klawitter et al., 2011). Application of the p38 chemical inhibitor SB202190 in human AF cells co-cultured with macrophages or stimulated with TNF- $\alpha$ caused a significant reduction in proinflammatory cytokines and prostaglandins, indicating that $\mathrm{p} 38$ blockage may be useful for the treatment of IDD (Kim et al., 2009). The anabolic, anti-catabolic and anti-inflammatory response of IVD cells treated with the p38 inhibitor SB202190 was confirmed in rabbit IVD cells exposed to inflammatory signals (Studer et al., 2008). On the other hand, the glycoprotein lactoferricin caused anabolic effects in bovine NP cells via activation of p38 and ERK, and this effect was reversed by treatment with the p38 inhibitor SB203580 or the ERK inhibitor PD98059 (Kim et al., 2011).

Importantly, multiple studies in the last decade suggest that MAPK inhibitors may also offer therapeutic potential for patients with sciatic nerve crush, spinal nerve ligation or disc herniation. In fact, MAP kinase activity has been shown to be elevated in conditions mentioned above (Doya et al., 2005; Ito et al., 2007; Jin et al., 2003; Kominato et al., 2003; Myers et al., 2003; Obata et al., 2004; Schafers et al., 2003; Zhuang et al., 2005; Zhuang et al., 2006). In light of this, asialo-erythropoietin, a nonerythropoietic cytokine, was recently shown to reduce levels of phosphorylated p38 and improve pain-related behaviour (as measured by von Frey filament testing) in a rat model of lumbar disc herniation (Sasaki et al., 2010). Furthermore, MAPK inhibitors seem to have the ability to reduce neuropathic pain. These include the use of JNK peptide inhibitor DJNKI-1 in a model of spinal nerve ligation (Zhuang et al., 2006), p38 inhibitor SB203580 in a model of spinal nerve ligation (Schafers et al., 2003) and p38 inhibitor SD-169 in a model of sciatic nerve crush (Myers et al., 2003).

However, despite the promising potential of MAPK inhibitors, their risk-benefit ratio remains controversial. This is because inhibition of MAPKs, which are involved in a multitude of physiological processes, may lead to 
detrimental side effects. Inhibition of the ERK-mediated pathway (regulator of growth factor signalling) and JNKmediated pathway (modulator of cell proliferation, differentiation and apoptosis) may cause general cytotoxicity. For instance, inhibition of the p38 MAPK pathway blocks chondrocyte differentiation (Jin et al., 2006; Li et al., 2010; Li et al., 2009). A careful screening will thus have to be done using MAPK inhibitors to treat IDD in order to rule out a potential anti-anabolic or toxic behaviour.

\section{Summary}

Based on existing information, NF- $\kappa \mathrm{B}$ and MAP kinases appear to be potentially ideal therapeutic targets to treat IDD. P38 MAPK inhibition, either via natural compounds (e.g. curcumin, triptolide) or synthetic compounds (e.g. SB202190, PD38059, SB203580), was shown to reduce inflammatory and catabolic responses in intervertebral disc cells and ameliorate stress-induced loss of matrix anabolism. Reduction of $\mathrm{NF}-\kappa \mathrm{B}$, either via genetic or pharmacologic intervention, also mitigates age-associated disc matrix proteoglycan loss. However, because these signalling pathways regulate a large number of genes in cellular response to a variety of stressors, general nondiscriminating inhibition of these pathways may produce unanticipated deleterious side effects, such as general toxicity, cell proliferation, or inhibition of anabolism and differentiation. Therefore, much more basic research is needed to gain a better understanding of these complex pathways and how their interactions determine the outcome of IDD treatment through inhibiting these pathways. In fact, we are only beginning to explore the pathways that regulate intervertebral disc homeostasis, degeneration and inflammation. A number of important questions still remain unanswered. It is still unclear whether NF- $\kappa B$ or MAPK activation levels correspond to the different stages of IDD, which physiologic stressors trigger their activation, and how disc matrix homeostasis is affected as the result of such activation. Future research will also have to address the distinct roles of specific MAPK isoforms, as well as the complex interplay of the reviewed signalling pathways. These and other insights will be crucial for identifying specific therapeutic molecular targets within these pathways in order to minimise the toxic side effects in the treatment of IDD through inhibiting these pathways.

\section{Acknowledgements}

This work was made possible by grants from AOSpine (SRN 02/103 and AOSBRC-07-03) (authors KW, NB), NIH (NIH R21 AG033046) (author NV), AO Fund (05K68) (author DK) and European Union FP7 ("GENODISC" project, HEALTH-F2-2008-201626) (author DK). We thank K. Ngo for his assistance on the graphic illustration in Fig. 1 and M. Klawitter, L. Quero and M. Hakozaki for technical assistance in obtaining results shown in Figs. 2 and 3.

\section{References}

Abu-Amer Y, Dowdy SF, Ross FP, Clohisy JC, Teitelbaum SL (2001) TAT fusion proteins containing tyrosine 42-deleted IkappaBalpha arrest osteoclastogenesis. J Biol Chem 276: 30499-30503.

Acharyya S, Villalta SA, Bakkar N, Bupha-Intr T, Janssen PM, Carathers M, Li ZW, Beg AA, Ghosh S, Sahenk Z, Weinstein M, Gardner KL, Rafael-Fortney JA, Karin M, Tidball JG, Baldwin AS, Guttridge DC (2007) Interplay of IKK/NF-kappaB signaling in macrophages and myofibers promotes muscle degeneration in Duchenne muscular dystrophy. J Clin Invest 117: 889-901.

Adams MA, McNally DS, Dolan P (1996) 'Stress' distributions inside intervertebral discs. The effects of age and degeneration. J Bone Joint Surg Br 78: 965-972.

Adams MA, Stefanakis M, Dolan P (2010) Healing of a painful intervertebral disc should not be confused with reversing disc degeneration: implications for physical therapies for discogenic back pain. Clin Biomech 25: 961-971.

Adler AS, Sinha S, Kawahara TL, Zhang JY, Segal E, Chang HY (2007) Motif module map reveals enforcement of aging by continual NF-kappaB activity. Genes Dev 21: 3244-3257.

Agarwal S, Long P, Seyedain A, Piesco N, Shree A, Gassner R (2003) A central role for the nuclear factorkappaB pathway in anti-inflammatory and proinflammatory actions of mechanical strain. FASEB J 17: 899-901.

Ahn KS, Sethi G, Chao TH, Neuteboom ST, Chaturvedi MM, Palladino MA, Younes A, Aggarwal BB (2007) Salinosporamide A (NPI-0052) potentiates apoptosis, suppresses osteoclastogenesis, and inhibits invasion through down-modulation of NF-kappaB regulated gene products. Blood 110: 2286-2295.

Akeda K, An H, Gemba T, Okuma M, Miyamoto K, Chujo T, Kitahara S, Masuda K (2005) A new gene therapy approach: In vivo transfection of naked NF-kB decoy oligonucleotide restored disc degeneration in the rabbit annular needle puncture model. Trans Orthop Res Soc 30:45.

Altindag O, Erel O, Soran N, Celik H, Selek S (2008) Total oxidative/anti-oxidative status and relation to bone mineral density in osteoporosis. Rheumatol Int 28: 317321.

Ariga K, Yonenobu K, Nakase T, Hosono N, Okuda S, Meng W, Tamura Y, Yoshikawa H (2003) Mechanical stress-induced apoptosis of endplate chondrocytes in organ-cultured mouse intervertebral discs: an ex vivo study. Spine 28: 1528-1533.

Auphan N, DiDonato JA, Rosette C, Helmberg A, Karin M (1995) Immunosuppression by glucocorticoids: inhibition of NF-kappa B activity through induction of I kappa B synthesis. Science 270: 286-290.

Bachmeier BE, Nerlich AG, Weiler C, Paesold G, Jochum M, Boos N (2007) Analysis of tissue distribution of TNF-alpha, TNF-alpha-receptors, and the activating TNF-alpha-converting enzyme suggests activation of the TNF-alpha system in the aging intervertebral disc. Ann N Y Acad Sci 1096: 44-54. 
Baeuerle PA, Henkel T (1994) Function and activation of NF-kappa B in the immune system. Annu Rev Immunol 12: 141-179.

Barnes PJ, Karin M (1997) Nuclear factor-kappaB: a pivotal transcription factor in chronic inflammatory diseases. N Engl J Med 336: 1066-1071.

Berenbaum F (2004) Signaling transduction: target in osteoarthritis. Curr Opin Rheumatol 16: 616-622.

Bernard D, Quatannens B, Begue A, Vandenbunder B, Abbadie C (2001) Antiproliferative and antiapoptotic effects of crel may occur within the same cells via the upregulation of manganese superoxide dismutase. Cancer Res 61: 2656-2664.

Bernard D, Gosselin K, Monte D, Vercamer C, Bouali F, Pourtier A, Vandenbunder B, Abbadie C (2004) Involvement of Rel/nuclear factor-kappaB transcription factors in keratinocyte senescence. Cancer Res 64: 472-481.

Boland MP (2001) DNA damage signalling and NFkappaB: implications for survival and death in mammalian cells. Biochem Soc Trans 29: 674-678.

Boutros T, Chevet E, Metrakos P (2008) Mitogenactivated protein (MAP) kinase/MAP kinase phosphatase regulation: roles in cell growth, death, and cancer. Pharmacol Rev 60: 261-310.

Bregegere F, Milner Y, Friguet B (2006) The ubiquitinproteasome system at the crossroads of stress-response and ageing pathways: a handle for skin care? Ageing Res Rev 5: 60-90.

Bubici C, Papa S, Dean K, Franzoso G (2006) Mutual cross-talk between reactive oxygen species and nuclear factor-kappa B: molecular basis and biological significance. Oncogene 25: 6731-6748.

Burke JG, Watson RW, McCormack D, Dowling FE, Walsh MG, Fitzpatrick JM (2002) Intervertebral discs which cause low back pain secrete high levels of proinflammatory mediators. J Bone Joint Surg Br 84: 196-201.

Chambard JC, Lefloch R, Pouyssegur J, Lenormand P (2007) ERK implication in cell cycle regulation. Biochim Biophys Acta 1773: 1299-1310.

Chen H, Wu L, Chen Y, Wang B (2001) [Effects of laminar shear stress on IL-8 mRNA expression in endothelial cells]. Sheng Wu Yi Xue Gong Cheng Xue Za Zhi 18: 64-67.

Chen Q, Ames BN (1994) Senescence-like growth arrest induced by hydrogen peroxide in human diploid fibroblast F65 cells. Proc Natl Acad Sci U S A 91: 4130 4134.

Cheng CC, Uchiyama Y, Hiyama A, Gajghate S, Shapiro IM, Risbud MV (2009) PI3K/AKT regulates aggrecan gene expression by modulating Sox 9 expression and activity in nucleus pulposus cells of the intervertebral disc. $\mathrm{J}$ Cell Physiol 221: 668-676.

Chou D, Samartzis D, Bellabarba C, Patel A, Luk KD, Kisser JM, Skelly AC (2011) Degenerative magnetic resonance imaging changes in patients with chronic low back pain: a systematic review. Spine 36: S43-53.

Conejo R, de Alvaro C, Benito M, Cuadrado A, Lorenzo M (2002) Insulin restores differentiation of Rastransformed $\mathrm{C} 2 \mathrm{C} 12$ myoblasts by inducing NF-kappaB through an AKT/P70S6K/p38-MAPK pathway. Oncogene 21: 3739-3753.
Crisostomo PR, Wang Y, Markel TA, Wang M, Lahm T, Meldrum DR (2008) Human mesenchymal stem cells stimulated by TNF-alpha, LPS, or hypoxia produce growth factors by an NF kappa B- but not JNK-dependent mechanism. Am J Physiol Cell Physiol 294: C675-682.

Cui Y, Yu J, Urban JP, Young DA (2010) Differential gene expression profiling of metalloproteinases and their inhibitors: a comparison between bovine intervertebral disc nucleus pulposus cells and articular chondrocytes. Spine 35: 1101-1108.

Dai S, Hirayama T, Abbas S, Abu-Amer Y (2004) The IkappaB kinase (IKK) inhibitor, NEMO-binding domain peptide, blocks osteoclastogenesis and bone erosion in inflammatory arthritis. J Biol Chem 279: 37219-37222.

Dent P, Yacoub A, Fisher PB, Hagan MP, Grant S (2003) MAPK pathways in radiation responses. Oncogene 22: 5885-5896.

Deschner J, Hofman CR, Piesco NP, Agarwal S (2003) Signal transduction by mechanical strain in chondrocytes. Curr Opin Clin Nutr Metab Care 6: 289-293.

Deshpande R, Khalili H, Pergolizzi RG, Michael SD, Chang MD (1997) Estradiol down-regulates LPS-induced cytokine production and NFkB activation in murine macrophages. Am J Reprod Immunol 38: 46-54.

Doya H, Ohtori S, Takahashi K, Aoki Y, Ino H, Takahashi Y, Moriya H, Yamashita T (2005) Extracellular signal-regulated kinase mitogen-activated protein kinase activation in the dorsal root ganglion (DRG) and spinal cord after DRG injury in rats. Spine 30: 2252-2256.

Elliott SF, Coon CI, Hays E, Stadheim TA, Vincenti MP (2002) Bcl-3 is an interleukin-1-responsive gene in chondrocytes and synovial fibroblasts that activates transcription of the matrix metalloproteinase 1 gene. Arthritis Rheum 46: 3230-3239.

Freemont AJ, Peacock TE, Goupille P, Hoyland JA, O’Brien J, Jayson MI (1997) Nerve ingrowth into diseased intervertebral disc in chronic back pain. Lancet 350: 178181.

Freund A, Patil CK, Campisi J (2010) p38MAPK is a novel DNA damage response-independent regulator of the senescence-associated secretory phenotype. EMBO J 30: 1536-1548.

Furia B, Deng L, Wu K, et al. (2002) Enhancement of nuclear factor-kappa B acetylation by coactivator $\mathrm{p} 300$ and HIV-1 Tat proteins. J Biol Chem 277: 4973-4980.

Ghosh S, Karin M (2002) Missing pieces in the NFkappaB puzzle. Cell 109 Suppl: S81-96.

Ghosh S, May MJ, Kopp EB (1998) NF-kappa B and Rel proteins: evolutionarily conserved mediators of immune responses. Annu Rev Immunol 16: 225-260.

Giardina C, Hubbard AK (2002) Growing old with nuclear factor-kappaB. Cell Stress Chaperones 7: 207-212.

Gogate SS, Nasser R, Shapiro IM, Risbud MV (2011) Hypoxic regulation of beta-1,3-glucuronyltransferase 1 expression in nucleus pulposus cells of the rat intervertebral disc: role of hypoxia-inducible factor proteins. Arthritis Rheum 63: 1950-1960.

Goupille P, Mulleman D, Paintaud G, Watier H, Valat JP (2007) Can sciatica induced by disc herniation be treated with tumor necrosis factor alpha blockade? Arthritis Rheum 56: 3887-3895. 
Gruber HE, Ingram JA, Norton HJ, Hanley EN, Jr. (2007) Senescence in cells of the aging and degenerating intervertebral disc: immunolocalization of senescenceassociated beta-galactosidase in human and sand rat discs. Spine 32: 321-327.

Gruber HE, Hoelscher GL, Ingram JA, Zinchenko N, Hanley EN, Jr. (2010) Senescent vs. non-senescent cells in the human annulus in vivo: cell harvest with laser capture microdissection and gene expression studies with microarray analysis. BMC Biotechnol 10: 5.

Hacker H, Karin M (2006) Regulation and function of IKK and IKK-related kinases. Sci STKE 357: re13.

Han J, Sun P (2007) The pathways to tumor suppression via route $\mathrm{p} 38$. Trends Biochem Sci 32: 364-371.

Hastreiter D, Ozuna RM, Spector M (2001) Regional variations in certain cellular characteristics in human lumbar intervertebral discs, including the presence of alpha-smooth muscle actin. J Orthop Res 19: 597-604.

Hayden MS, Ghosh S (2008) Shared principles in NFkappaB signaling. Cell 132: 344-362.

Helenius M, Hanninen M, Lehtinen SK, Salminen A (1996a) Aging-induced up-regulation of nuclear binding activities of oxidative stress responsive NF-kB transcription factor in mouse cardiac muscle. J Mol Cell Cardiol 28: 487-498.

Helenius M, Hanninen M, Lehtinen SK, Salminen A (1996b) Changes associated with aging and replicative senescence in the regulation of transcription factor nuclear factor-kappa B. Biochem J 318: 603-608.

Hiyama A, Sakai D, Tanaka M, Arai F, Nakajima D, Abe K, Mochida J (2011) The relationship between the Wnt/beta-catenin and TGF-beta/BMP signals in the intervertebral disc cell. J Cell Physiol 226: 1139-1148.

Holmes-McNary M, Baldwin AS, Jr. (2000) Chemopreventive properties of trans-resveratrol are associated with inhibition of activation of the IkappaB kinase. Cancer Res 60: $3477-3483$.

Hoyland JA, Le Maitre C, Freemont AJ (2008) Investigation of the role of IL- 1 and TNF in matrix degradation in the intervertebral disc. Rheumatology 47: 809-814.

Huang P, Han J, Hui L (2010) MAPK signaling in inflammation-associated cancer development. Protein Cell 1: 218-226.

Imajo M, Tsuchiya Y, Nishida E (2006) Regulatory mechanisms and functions of MAP kinase signaling pathways. IUBMB Life 58: 312-317.

Ito T, Ohtori S, Inoue G, Koshi T, Doya H, Ozawa T, Saito T, Moriya H, Takahashi K (2007) Glial phosphorylated p38 MAP kinase mediates pain in a rat model of lumbar disc herniation and induces motor dysfunction in a rat model of lumbar spinal canal stenosis. Spine 32: 159167.

Iwasa H, Han J, Ishikawa F (2003) Mitogen-activated protein kinase p38 defines the common senescencesignalling pathway. Genes Cells 8: 131-144.

Ji C, Kozak KR, Marnett LJ (2001) IkappaB kinase, a molecular target for inhibition by 4-hydroxy-2-nonenal. J Biol Chem 276: 18223-18228.

Jin SX, Zhuang ZY, Woolf CJ, Ji RR (2003) p38 mitogen-activated protein kinase is activated after a spinal nerve ligation in spinal cord microglia and dorsal root ganglion neurons and contributes to the generation of neuropathic pain. J Neurosci 23: 4017-4022.

Jin EJ, Lee SY, Choi YA, Jung JC, Bang OS, Kang SS (2006) BMP-2-enhanced chondrogenesis involves p38 MAPK-mediated down-regulation of Wnt-7a pathway. Mol Cells 22: 353-359.

Jobin C, Bradham CA, Russo MP, Juma B, Narula AS, Brenner DA, Sartor RB (1999) Curcumin blocks cytokinemediated NF-kappa B activation and proinflammatory gene expression by inhibiting inhibitory factor I-kappa B kinase activity. J Immunol 163: 3474-3483.

Kaminska B (2005) MAPK signalling pathways as molecular targets for anti-inflammatory therapy--from molecular mechanisms to therapeutic benefits. Biochim Biophys Acta 1754: 253-262.

Karin M, Ben-Neriah Y (2000) Phosphorylation meets ubiquitination: the control of NF-[kappa]B activity. Annu Rev Immunol 18: 621-663.

Karin M, Lin A (2002) NF-kappaB at the crossroads of life and death. Nat Immunol 3: 221-227.

Kim HJ, Chang EJ, Kim HM, Lee SB, Kim HD, Su Kim G, Kim HH (2006) Antioxidant alpha-lipoic acid inhibits osteoclast differentiation by reducing nuclear factor-kappaB DNA binding and prevents in vivo bone resorption induced by receptor activator of nuclear factorkappaB ligand and tumor necrosis factor-alpha. Free Radic Biol Med 40: 1483-1493.

Kim JH, Studer RK, Vo NV, Sowa GA, Kang JD (2009) p38 MAPK inhibition selectively mitigates inflammatory mediators and VEGF production in AF cells co-cultured with activated macrophage-like THP-1 cells. Osteoarthritis Cart 17: 1662-1669.

Kim JS, Ellman MB, An HS, Yan D, van Wijnen AJ, Murphy G, Hoskin DW, Im HJ (2012) Lactoferricin mediates anabolic and anti-catabolic effects in the intervertebral disc. J Cell Physiol 227: 1512-1520.

Klawitter M, Quero L, Klasen J, Liebscher T, Nerlich A, Boos N, Wuertz K (2011) Triptolide exhibits antiinflammatory, anti-catabolic as well as anabolic effects and suppresses TLR expression and MAPK activity in IL-1beta treated human intervertebral disc cells. Eur Spine $\mathrm{J}$ (in press).

Kletsas D (2009) Senescent cells in the intervertebral disc: numbers and mechanisms. Spine J 9: 677-678.

Koh G, Teong HF, Clement MV, Hsu D, Thiagarajan PS (2006) A decompositional approach to parameter estimation in pathway modeling: a case study of the Akt and MAPK pathways and their crosstalk. Bioinformatics 22: e271-280.

Kominato Y, Tachibana T, Dai Y, Tsujino H, Maruo S, Noguchi K (2003) Changes in phosphorylation of ERK and Fos expression in dorsal horn neurons following noxious stimulation in a rat model of neuritis of the nerve root. Brain Res 967: 89-97.

Kopp E, Ghosh S (1994) Inhibition of NF-kappa B by sodium salicylate and aspirin. Science 265: 956-959.

Korhonen P, Helenius M, Salminen A (1997) Agerelated changes in the regulation of transcription factor NF-kappa B in rat brain. Neurosci Lett 225: 61-64.

Kriete A, Mayo KL, Yalamanchili N, Beggs W, Bender P, Kari C, Rodeck U (2008) Cell autonomous expression 
of inflammatory genes in biologically aged fibroblasts associated with elevated NF-kappaB activity. Immun Ageing 5: 5 .

Kyriakis JM, Avruch J (2001) Mammalian mitogenactivated protein kinase signal transduction pathways activated by stress and inflammation. Physiol Rev 81: 807-869.

Le Maitre CL, Freemont AJ, Hoyland JA (2005) The role of interleukin-1 in the pathogenesis of human intervertebral disc degeneration. Arthritis Res Ther 7: R732-745.

Le Maitre CL, Hoyland JA, Freemont AJ (2007) Catabolic cytokine expression in degenerate and herniated human intervertebral discs: IL-1beta and TNFalpha expression profile. Arthritis Res Ther 9: R77.

Lee AC, Fenster BE, Ito H, Takeda K, Bae NS, Hirai T, Yu ZX, Ferrans VJ, Howard BH, Finkel T (1999) Ras proteins induce senescence by altering the intracellular levels of reactive oxygen species. J Biol Chem 274: 79367940.

Li J, Zhao Z, Yang J, Liu J, Wang J, Li X, Liu Y (2009) p38 MAPK mediated in compressive stress-induced chondrogenesis of rat bone marrow MSCs in 3D alginate scaffolds. J Cell Physiol 221: 609-617.

Li J, Zhao Z, Liu J, Huang N, Long D, Wang J, Li X, Liu Y (2010) MEK/ERK and p38 MAPK regulate chondrogenesis of rat bone marrow mesenchymal stem cells through delicate interaction with TGF-beta1/Smads pathway. Cell Prolif 43: 333-343.

Liacini A, Sylvester J, Li WQ, Huang W, Dehnade F, Ahmad M, Zafarullah M (2003) Induction of matrix metalloproteinase-13 gene expression by TNF-alpha is mediated by MAP kinases, AP-1, and NF-kappaB transcription factors in articular chondrocytes. Exp Cell Res 288: 208-217.

Marcu KB, Otero M, Olivotto E, Borzi RM, Goldring MB (2010) NF-kappaB signaling: multiple angles to target OA. Curr Drug Targets 11: 599-613.

Maruyama J, Naguro I, Takeda K, Ichijo H (2009) Stress-activated MAP kinase cascades in cellular senescence. Curr Med Chem 16: 1229-1235.

Mavrogonatou E, Kletsas D (2009) High osmolality activates the $\mathrm{G} 1$ and $\mathrm{G} 2$ cell cycle checkpoints and affects the DNA integrity of nucleus pulposus intervertebral disc cells triggering an enhanced DNA repair response. DNA Repair 8: 930-943.

Mavrogonatou E, Kletsas D (2010) Effect of varying osmotic conditions on the response of bovine nucleus pulposus cells to growth factors and the activation of the ERK and Akt pathways. J Orthop Res 28: 1276-1282.

Mavrogonatou E, Kletsas D (2011) Differential response of nucleus pulposus intervertebral disc cells to high salt, sorbitol and urea. J Cell Physiol (in press).

May MJ, Ghosh S (1998) Signal transduction through NF-kappa B. Immunol Today 19: 80-88.

Mengshol JA, Vincenti MP, Coon CI, Barchowsky A, Brinckerhoff CE (2000) Interleukin-1 induction of collagenase 3 (matrix metalloproteinase 13) gene expression in chondrocytes requires p38, c-Jun N-terminal kinase, and nuclear factor kappaB: differential regulation of collagenase 1 and collagenase 3. Arthritis Rheum 43: 801-811.

Murakami S, Lefebvre V, de Crombrugghe B (2000) Potent inhibition of the master chondrogenic factor Sox 9 gene by interleukin-1 and tumor necrosis factor-alpha. J Biol Chem 275: 3687-3692.

Myers RR, Sekiguchi Y, Kikuchi S, Scott B, Medicherla S, Protter A, Campana WM (2003) Inhibition of p38 MAP kinase activity enhances axonal regeneration. Exp Neurol 184: 606-614.

Nasto LA, Seo HY, Robinson AR, Tilstra JS, Clauson CL, Sowa GA, Ngo K, Dong Q, Pola E, Lee JY, Niedernhofer LJ, Kang JD, Robbins PD, Vo NV (2011) Inhibition of NF-KB activity ameliorates age-associated disc degeneration in a mouse model of accelerated aging. Spine (in press).

Nerlich AG, Bachmeier BE, Schleicher E, Rohrbach H, Paesold G, Boos N (2007) Immunomorphological analysis of RAGE receptor expression and NF-kappaB activation in tissue samples from normal and degenerated intervertebral discs of various ages. Ann N Y Acad Sci 1096: 239-248.

Niederberger E, Tegeder I, Schafer C, Seegel M, Grosch S, Geisslinger G (2003) Opposite effects of rofecoxib on nuclear factor-kappaB and activating protein-1 activation. J Pharmacol Exp Ther 304: 1153-1160.

Niu CC, Yuan LJ, Chen LH, Lin SS, Tsai TT, Liao JC, Lai PL, Chen WJ (2011) Beneficial effects of hyperbaric oxygen on human degenerated intervertebral disk cells via suppression of IL-1beta and p38 MAPK signal. J Orthop Res 29: 14-19.

Obata K, Yamanaka H, Kobayashi K, Dai Y, Mizushima T, Katsura H, Fukuoka T, Tokunaga A, Noguchi K (2004) Role of mitogen-activated protein kinase activation in injured and intact primary afferent neurons for mechanical and heat hypersensitivity after spinal nerve ligation. $\mathrm{J}$ Neurosci 24: 10211-10222.

Oh I, Park S, Son J, Chung J, Kim Y (2010) Glucocorticoid mechanism of inhibition of the inflammatory cells in lumbar intervertebral disc cells stimulated by TNF-alpha production of nuclear factor-kappaB. J Korean Orthop Res Soc. 13: 80-87.

Ohba T, Haro H, Ando T, Koyama K, Hatsushika K, Suenaga F, Ohnuma Y, Nakamura Y, Katoh R, Ogawa H, Hamada Y, Nakao A (2008) A potential role of thymic stromal lymphopoietin in the recruitment of macrophages to mouse intervertebral disc cells via monocyte chemotactic protein 1 induction: implications for herniated discs. Arthritis Rheum 58: 3510-3519.

Ohba T, Haro H, Ando T, Wako M, Suenaga F, Aso Y, Koyama K, Hamada Y, Nakao A (2009) TNF-alphainduced NF-kappaB signaling reverses age-related declines in VEGF induction and angiogenic activity in intervertebral disc tissues. J Orthop Res 27: 229-235.

Oliver KM, Garvey JF, Ng CT, Veale DJ, Fearon U, Cummins EP, Taylor CT (2009) Hypoxia activates NFkappaB-dependent gene expression through the canonical signaling pathway. Antioxid Redox Signal 11: 2057-2064.

Olmarker K, Rydevik B (1998) [New information concerning pain caused by herniated disk and sciatica. Exposure to disk tissue sensitizes the nerve roots]. Lakartidningen 95: 5618-5622.

Ozawa T, Ohtori S, Inoue G, Aoki Y, Moriya H, Takahashi K (2006) The degenerated lumbar intervertebral disc is innervated primarily by peptide-containing sensory nerve fibers in humans. Spine 31: 2418-2422. 
Palombella VJ, Rando OJ, Goldberg AL, Maniatis T (1994) The ubiquitin-proteasome pathway is required for processing the NF-kappa B1 precursor protein and the activation of NF-kappa B. Cell 78: 773-785.

Papadopoulou A, Kletsas D (2011) Human lung fibroblasts prematurely senescent after exposure to ionizing radiation enhance the growth of malignant lung epithelial cells in vitro and in vivo. Int J Oncol 39: 989-999.

Pearson G, Robinson F, Beers Gibson T, Xu BE, Karandikar M, Berman K, Cobb MH (2001) Mitogenactivated protein (MAP) kinase pathways: regulation and physiological functions. Endocr Rev 22: 153-183.

Peffers MJ, Milner PI, Tew SR, Clegg PD (2010) Regulation of SOX9 in normal and osteoarthritic equine articular chondrocytes by hyperosmotic loading. Osteoarthritis Cart 18: $1502-1508$.

Peng B, Wu W, Hou S, Li P, Zhang C, Yang Y (2005) The pathogenesis of discogenic low back pain. J Bone Joint Surg Br 87: 62-67.

Peng B, Hao J, Hou S, Wu W, Jiang D, Fu X, Yang Y (2006) Possible pathogenesis of painful intervertebral disc degeneration. Spine 31: 560-566.

Petit A, Yao G, Rowas SA, Gawri R, Epure L, Antoniou J, Mwale F (2011) Effect of synthetic link N peptide on the expression of type I and type II collagens in human intervertebral disc cells. Tissue Eng Part A 17: 899-904.

Pichika R, Akeda K, Gemba T, Miyamoto K, An H, Masuda K (2005) Transcription factor decoy for NF-kB inhibits the appearance of active MMPs and ADAMTS4 in the medium of human intervertebral disc cells cultured in alginate. Proceedings of the ISSLS.

Poveda L, Hottiger M, Boos N, Wuertz K (2009) Peroxynitrite induces gene expression in intervertebral disc cells. Spine 34: 1127-1133.

Pratsinis H, Kletsas D (2007) PDGF, bFGF and IGFI stimulate the proliferation of intervertebral disc cells in vitro via the activation of the ERK and Akt signaling pathways. Eur Spine J 16: 1858-1866.

Pratsinis H, Kletsas D (2008) Growth factors in intervertebral disc homeostasis. Connect Tissue Res 49: 273-276.

Ramana KV, Friedrich B, Srivastava S, Bhatnagar A, Srivastava SK (2004) Activation of nuclear factor-kappaB by hyperglycemia in vascular smooth muscle cells is regulated by aldose reductase. Diabetes 53: 2910-2920.

Risbud MV, Fertala J, Vresilovic EJ, Albert TJ, Shapiro IM (2005a) Nucleus pulposus cells upregulate PI3K/Akt and MEK/ERK signaling pathways under hypoxic conditions and resist apoptosis induced by serum withdrawal. Spine 30: 882-889.

Risbud MV, Guttapalli A, Albert TJ, Shapiro IM (2005b) Hypoxia activates MAPK activity in rat nucleus pulposus cells: regulation of integrin expression and cell survival. Spine 30: 2503-2509.

Risbud MV, Di Martino A, Guttapalli A, Seghatoleslami R, Denaro V, Vaccaro AR, Albert TJ, Shapiro IM (2006) Toward an optimum system for intervertebral disc organ culture: TGF-beta 3 enhances nucleus pulposus and anulus fibrosus survival and function through modulation of TGFbeta-R expression and ERK signaling. Spine 31: 884-890.
Roberts S, Caterson B, Menage J, Evans EH, Jaffray DC, Eisenstein SM (2000) Matrix metalloproteinases and aggrecanase: their role in disorders of the human intervertebral disc. Spine 25: 3005-3013.

Roberts S, Evans EH, Kletsas D, Jaffray DC, Eisenstein SM (2006) Senescence in human intervertebral discs. Eur Spine J 15 Suppl 3: S312-316.

Rodrigues A, Queiroz DB, Honda L, Silva EJ, Hall SH, Avellar MC (2008) Activation of toll-like receptor 4 (TLR4) by in vivo and in vitro exposure of rat epididymis to lipopolysaccharide from Escherichia Coli. Biol Reprod 79: 1135-1147.

Roux PP, Blenis J (2004) ERK and p38 MAPKactivated protein kinases: a family of protein kinases with diverse biological functions. Microbiol Mol Biol Rev 68: 320-344.

Sasaki N, Sekiguchi M, Kikuchi S, Konno S (2010) Effects of asialo-erythropoietin on pain-related behavior and expression of phosphorylated-p38 map kinase and tumor necrosis factor-alpha induced by application of autologous nucleus pulposus on nerve root in rat. Spine 36: E86-94.

Schafers M, Svensson CI, Sommer C, Sorkin LS (2003) Tumor necrosis factor-alpha induces mechanical allodynia after spinal nerve ligation by activation of p38 MAPK in primary sensory neurons. J Neurosci 23: 2517-2521.

Seguin CA, Bojarski M, Pilliar RM, Roughley PJ, Kandel RA (2006) Differential regulation of matrix degrading enzymes in a TNFalpha-induced model of nucleus pulposus tissue degeneration. Matrix Biol 25: 409-418.

Seguin CA, Pilliar RM, Madri JA, Kandel RA (2008) TNF-alpha induces MMP2 gelatinase activity and MT1MMP expression in an in vitro model of nucleus pulposus tissue degeneration. Spine 33: 356-365.

Seitz CS, Deng H, Hinata K, Lin Q, Khavari PA (2000) Nuclear factor kappaB subunits induce epithelial cell growth arrest. Cancer Res 60: 4085-4092.

Sen R, Baltimore D (1986) Inducibility of kappa immunoglobulin enhancer-binding protein Nf-kappa B by a posttranslational mechanism. Cell 47: 921-928.

Sethi G, Sung B, Aggarwal BB (2008) Nuclear factorkappaB activation: from bench to bedside. Exp Biol Med 233: 21-31.

Shakibaei M, Csaki C, Nebrich S, Mobasheri A (2008) Resveratrol suppresses interleukin-1beta-induced inflammatory signaling and apoptosis in human articular chondrocytes: potential for use as a novel nutraceutical for the treatment of osteoarthritis. Biochem Pharmacol 76: 1426-1439.

Shamji MF, Setton LA, Jarvis W, So S, Chen J, Jing L, Bullock R, Isaacs RE, Brown C, Richardson WJ (2010) Proinflammatory cytokine expression profile in degenerated and herniated human intervertebral disc tissues. Arthritis Rheum 62: 1974-1982.

Studer RK, Gilbertson LG, Georgescu H, Sowa G, Vo N, Kang JD (2008) p38 MAPK inhibition modulates rabbit nucleus pulposus cell response to IL-1. J Orthop Res 26: 991-998.

Surh YJ, Han SS, Keum YS, Seo HJ, Lee SS (2000) Inhibitory effects of curcumin and capsaicin on phorbol ester-induced activation of eukaryotic transcription factors, NF-kappaB and AP-1. Biofactors 12: 107-112. 
Suzuki M, Inoue G, Gemba T, Watanabe T, Ito T, Koshi T, Yamauchi K, Yamashita M, Orita S, Eguchi Y, Ochiai N, Kishida S, Takaso M, Aoki Y, Takahashi K, Ohtori S (2009) Nuclear factor-kappa B decoy suppresses nerve injury and improves mechanical allodynia and thermal hyperalgesia in a rat lumbar disc herniation model. Eur Spine J 18: 1001-1007.

Tsai TT, Guttapalli A, Agrawal A, Albert TJ, Shapiro IM, Risbud MV (2007a) MEK/ERK signaling controls osmoregulation of nucleus pulposus cells of the intervertebral disc by transactivation of TonEBP/OREBP. J Bone Miner Res 22: 965-974.

Tsai TT, Guttapalli A, Oguz E, Chen LH, Vaccaro AR, Albert TJ, Shapiro IM, Risbud MV (2007b) Fibroblast growth factor- 2 maintains the differentiation potential of nucleus pulposus cells in vitro: implications for cell-based transplantation therapy. Spine 32: 495-502.

Uchiyama Y, Cheng CC, Danielson KG, Mochida J, Albert TJ, Shapiro IM, Risbud MV (2007) Expression of acid-sensing ion channel 3 (ASIC3) in nucleus pulposus cells of the intervertebral disc is regulated by p75NTR and ERK signaling. J Bone Miner Res 22: 1996-2006.

Ulrich JA, Liebenberg EC, Thuillier DU, Lotz JC (2007) ISSLS prize winner: repeated disc injury causes persistent inflammation. Spine 32: 2812-2819.

Urban JP (2002) The role of the physicochemical environment in determining disc cell behaviour. Biochem Soc Trans 30: 858-864.

Wagner EF, Nebreda AR (2009) Signal integration by JNK and p38 MAPK pathways in cancer development. Nat Rev Cancer 9: 537-549.

Wako M, Ohba T, Ando T, Arai Y, Koyama K, Hamada Y, Nakao A, Haro H (2008) Mechanism of signal transduction in tumor necrosis factor-like weak inducer of apoptosis-induced matrix degradation by MMP-3 upregulation in disc tissues. Spine 33: 2489-2494.

Wang W, Chen JX, Liao R, Deng Q, Zhou JJ, Huang S, Sun P (2002) Sequential activation of the MEKextracellular signal-regulated kinase and MKK3/6-p38 mitogen-activated protein kinase pathways mediates oncogenic ras-induced premature senescence. Mol Cell Biol 22: 3389-3403.

Wang Z, Hutton WC, Yoon ST (2012) BMP-7 suppresses TNF-mediated induction of the aggrecanases ADAMTS4/5 through antagonized activity of the transcription factor NF-қB in the intervertebral discs cells. Trans Orthop Res Soc 37: 65.

Weiler C, Nerlich AG, Zipperer J, Bachmeier BE, Boos N (2002) 2002 SSE Award Competition in Basic Science: expression of major matrix metalloproteinases is associated with intervertebral disc degradation and resorption. Eur Spine J 11: 308-320.

Weiler C, Nerlich AG, Bachmeier BE, Boos N (2005) Expression and distribution of tumor necrosis factor alpha in human lumbar intervertebral discs: a study in surgical specimen and autopsy controls. Spine 30: 44-53.

Wu GS (2004) The functional interactions between the p53 and MAPK signaling pathways. Cancer Biol Ther 3: 156-161.

Wu ZH, Shi Y, Tibbetts RS, Miyamoto S (2006) Molecular linkage between the kinase ATM and NF-kappaB signaling in response to genotoxic stimuli. Science 311: 1141-1146.

Wuertz K, Quero L, Sekiguchi M, Klawitter M, Nerlich A, Konno S, Kikuchi S, Boos N (2011) The red wine polyphenol resveratrol shows promising potential for the treatment of nucleus pulposus mediated pain in vitro and in vivo. Spine (in press).

Xia M, Zhu Y (2010) Fibronectin fragment activation of ERK increasing integrin alpha and beta subunit expression to degenerate nucleus pulposus cells. J Orthop Res 29: 556-561.

Xiao ZQ, Majumdar AP (2000) Induction of transcriptional activity of AP-1 and NF-kappaB in the gastric mucosa during aging. Am J Physiol Gastrointest Liver Physiol 278: G855-865.

Yu ZG, Xu N, Wang WB, Pan SH, Li KS, Liu JK (2009) Interleukin-1 inhibits Sox9 and collagen type II expression via nuclear factor-kappaB in the cultured human intervertebral disc cells. Chin Med J 122: 2483-2488.

Zarubin T, Han J (2005) Activation and signaling of the p38 MAP kinase pathway. Cell Res 15: 11-18.

Zhuang ZY, Gerner P, Woolf CJ, Ji RR (2005) ERK is sequentially activated in neurons, microglia, and astrocytes by spinal nerve ligation and contributes to mechanical allodynia in this neuropathic pain model. Pain 114: 149-159.

Zhuang ZY, Wen YR, Zhang DR, Borsello T, Bonny C, Strichartz GR, Decosterd I, Ji RR (2006) A peptide c-Jun $\mathrm{N}$-terminal kinase (JNK) inhibitor blocks mechanical allodynia after spinal nerve ligation: respective roles of JNK activation in primary sensory neurons and spinal astrocytes for neuropathic pain development and maintenance. J Neurosci 26: 3551-3560.

\section{Web References}

1. Gilmore T http://www.bu.edu/nf-kb/ [20-08-2011].

2. Gilmore T www.nf-kb.org [20-08-2011].

\section{Discussion with Reviewers}

Reviewer I: Would there ever be any use of inhibitors of intracellular signalling pathways such as NFkB, in targeting disease, given their usually crucial role in other processes? Authors: The authors believe that NF- $\mathrm{BB}$ and/or MAP kinases are potentially promising drug targets, at least for diseases which are characterised by aberrant activation of these pathways, e.g. certain types of cancer or inflammatory diseases. Abnormal hyperactivation of these intracellular signalling pathways in diseased IVD tissue of patients with discogenic back pain needs to be confirmed prior to contemplating the use of inhibitors of these pathways as therapeutic treatment. However, in order to minimise potential side effects that would almost certainly occur with systemic delivery, methods for targeted delivery (i.e. limiting the action to the desired tissue, in this case the IVD) are needed. Furthermore, efficacy and safety need to be assessed and ascertained by tightly controlling the duration and magnitude of inhibition (e.g. by using an appropriate regulated slow release system). 
Reviewer II: Many of the therapeutic agents targeted for inhibition of transcription factors have not been successful in clinical trials, primarily due to their diverse effects in various cells and situations. Do the authors believe that these agents will benefit patients with IVD disease? If so, what is the potential therapeutic targets and delivery methods?

Authors: As NF- $\kappa \mathrm{B}$ or MAP kinases play essential roles in inflammatory responses, these signalling pathways may be relevant therapeutic targets. In fact, many drugs that have been used for decades have most recently been shown to interfere with these signalling pathways, e.g. glucocorticoids or acetylsalicylic acid. In addition, much research effort has been undertaken to develop novel NF$\kappa \mathrm{B}$ or MAPK inhibitors. However, a general inhibition of $\mathrm{NF}-\kappa \mathrm{B}$ or MAPK signalling when treating inflammationrelated diseases such as IDD could cause undesirable, detrimental side effects in many other tissues or organs. Disc tissue-specific delivery system might be necessary to control the respective signalling pathway within the IVD, while not affecting other tissues. Thus, IVD-specific application of inhibitors, e.g. by intradiscal injection or via gene therapy approaches, may enable such a cell specific molecular intervention. Despite ongoing clinical trials that use either NF- $\kappa$ B (e.g. by PS-1145, SPC-839 or SC-514) or p38 MAPK (SB-681323, RO4402257, PH-797804) inhibitors for various diseases, such as atopic dermatitis and rheumatoid arthritis, many fundamental aspects will need to be evaluated both in in vitro studies and in appropriate animal models before these approaches become realistic therapeutic options for IDD patients. Despite these challenges, the NF- $\kappa \mathrm{B}$ and MAPK signalling pathways remain the most relevant and promising therapeutic targets for inflammation-related diseases such as IDD. 